Working Paper No.2000/1

\title{
MANAGING THE US BASE ISSUE \\ IN OKINAWA: A TEST FOR \\ JAPANESE DEMOCRACY
}

Aurelia George Mulgan

Canberra

January 2000

National Library of Australia

Cataloguing -in -Publication Entry

Mulgan, Aurelia George

Managing the US base issue in Okinawa: A test for Japanese democracy

ISBN $073153106 \mathrm{X}$

1. Military bases, American - Political aspects - Japan.

2. United States - Armed Forces - Japan - Okinawa Island.

3. Japan - Foreign relations - United States. 4. United States -

Foreign rela tions - Japan. 5. United States - Military relations -

Japan. I. Title. (Series: Working paper (Australian National University.

Dept. of International Relations); 2000/1).

355.70952

(C) A. George Mulgan 



\section{DEPARTMENT OF INTERNATIONAL RELATIONS}

\section{WORKING PAPERS}

The department's working paper series seeks to provide readers with access to current research on international relations. Reflecting the wide range of interest in the department, it will include topics on global international politics and the international political economy, the Asian-Pacific region and issues of concern to Australian foreign policy.

Publication as a 'Working Paper' does not preclude subsequent publication in scholarly journals or books, indeed it may facilitate publication by providing feedback from readers to authors.

Unless otherwise stated, publications of the Department of International Relations are presented without endorsement as contributions to the public

record and debate. Authors are responsible for their own analysis and conclusions.

Department of International Relations Research School of Pacific and Asian Studies Australian National University

Canberra ACT Australia 


\begin{abstract}
The domestic politics of US base management in Okinawa has become more problematic since the September 1995 rape of a twelve-year old Japanese schoolgirl by three American servicemen. More than any other single event in recent times, this act catalysed waves of protest against the presence of US forces in Okinawa and a defiant challenge by the former prefectural governor, Ota Masahide, to the central government's rights and prerogatives on baserelated issues. How the Okinawa base problem has been handled by the central government since late 1995 generates insights into the workings of Japanese democracy: the extent to which individual property rights are subordinated to national policies; the level of judicial independence from political interference; the use of economic compensation as an adjunct to more coercive instruments of state authority; the balance of power between central and local governments; the role of bureaucrats as political and electoral agents; the level of state responsiveness to minority interests; and the effectiveness of local protest movements in eliciting concessions from national policy makers.

In addition to assertions of superior executive, statutory and legislative authority, political and bureaucratic élites in Tokyo have deployed a twopronged strategy for dealing with the Okinawa base problem: economic blandishments combined with limited relocation of bases and base functions, plus some amelioration of the noxious spin -offs from bases for the Okinawan people. While these concessions represent only a qualified victory for the anti base movement in Okinawa, both the US and Japanese governments now accept that they must respond constructively to popular protests against the US force presence in Japan, that base-related issues can no longer be ignored or shunted aside, and that these issues must be factored into the IS-Japan security relationship.
\end{abstract}




\title{
MANAGING THE US BASE ISSUE IN OKINAWA: A TEST FOR JAPANESE DEMOCRACY
}

\author{
Aurelia George Mulgan ${ }^{1}$
}

\begin{abstract}
Managing issues relating to US military bases in Okinawa engages politics on three levels: the 'high' politics of US-Japan security relations, the 'low' politics of US base-local community relations, and the meso- or intermediate level of political interaction between local antibase elements and the national authorities. Although in practice these levels of politics are far from discrete, the concern of this paper is with the meso-level: the interaction of central political, bureaucratic and judicial élites with local antibase leaders and citizens in Okinawa over matters such as base reduction and relocation, and the renewal of base leases. $^{2}$

The domestic politics of US base management in Okinawa has become more problematic since the September 1995 rape of a 12 -year old Japanese schoolgirl by three American servicemen. More than any other single event in recent times, this act catalysed waves of protest against the presence of US forces in Okinawa and a defiant challenge by the former prefectural governor, Ota Masahide, to the central government's rights and prerogatives on base-related issues. How the Okinawa base problem has been handled by the central government since late 1995 generates insights into the workings of Japanese democracy: the extent to which individual property rights are subordinated to national policies; the level of judicial independence from political interference; the use of economic compensation as an adjunct to more coercive instruments of state authority; the balance of power between central and local governments; the role of bureaucrats as political and electoral agents; the level of state responsiveness to minority interests; and the effectiveness of local protest movements in eliciting concessions from national policy makers.
\end{abstract}

1 School of Politics, University of New South Wales, Australian Defence Force Academy. Paper prepared for the Japanese Studies Association of Australia Biennial Conference, 1-4 December 1999, Central Queensland University, Rockhampton Campus.

2 For the concept of meso-level interaction as applied to citizens' movements in Japan, see Broadbent (1998: 99). 


\section{The historical legacy}

In its genesis, the Okinawa base problem embodies a conspicuously undemocratic legacy. The installation of US bases on Okinawa was not subject to the customary democratic consent processes normally associated with the siting of large projects and facilities that have potentially negative social and environmental effects. Following almost three decades of US military occupation between 1945 and 1972, a period during which Okinawa was given over almost entirely to US bases, the American and Japanese governments decided to retain the bases on Okinawa following its reversion to Japanese sovereignty in May 1972. For the Okinawan people, the continuing American presence was a fait accompli, a legacy of history, and a matter on which they enjoyed no meaningful consultation and on which they had no direct say. The joint statement issued by Prime Minister Sato and President Nixon in November 1969 which presaged the return of Okinawa to Japan stated:

...even after the reversion the United States would retain facilities and areas in Okinawa required for security objectives common to both countries, on the basis of the Japan-U.S. Security Treaty (Defense Agency 1997: 232).

In fact, Governor Yara Chobyo had to accept the bases as the price of reversion. For this reason the Okinawan reversion (fukki) movement was considered a failure as an anti-base movement (Tanji Miyume, personal communication, November 1999).

\section{Institutionalised discrimination}

The US bases on Okinawa have unquestionably constituted a form of institutionalised discrimination against the Okinawan people. The issue they raise is fundamentally one of the equitable distribution of the social, environmental and economic costs of the American military presence in Japan. Aside from argument that the American bases on Okinawa actually infringe the constitu tional rights of Okinawans, ${ }^{3}$ it is an undeniable fact that Okinawa bears a disproportionate

3 According to Taira, the way in which the Okinawans live in the shadow of the US bases makes a mockery of the declaration in the Preamble to the Japanese Constitution, which states that 'all peoples of the world have the right to live in peace, free from fear and want'. He argues that 'life for Okinawans involves a high level of fear and anxiety that they might be robbed, raped, or killed by American soldiers, or that disasters might descend out of the blue or crop up from nowhere at any time' (Taira 1997: 2). 
burden of the American military presence in Japan compared to the rest of Japan. 4

In January 1972, just prior to the Okinawa reversion, Prime Minister Sato and President Nixon jointly confirmed that:

...1) Prime Minister Sato found it necessary to realign or reduce USFJ [United States Forces Japan] facilities stationed in Okinawa, particularly those in densely populated areas and areas closely related to industrial development, as much as possible after the reversion, and 2) President Nixon promised to consider these factors in adjusting these facilities and areas after the reversion (Defense Agency 1997: 232).

In practice, however, the number of US bases and the square kilometres of land they occupied declined precipitously just before reversion in May 1972, but underwent only incremental reduction after that, particularly in terms of area (see Defense Agency 1998: 267). More importantly, after reversion, the number of US bases in Okinawa expanded as a proportion of the total in Japan. ${ }^{5}$ As Giarra explains (1999: 118):

In the years before...reversion, Tokyo pressed to have virtually all U.S. ground forces eliminated from mainland Japanese bases. In a natural process, most U.S. ground forces consolidated and relocated on Okinawa, where U.S. control made such actions relatively easy. The legacy of that process is the current concentration of U.S. forces on Okinawa.

Not only was the Japanese government unwilling to consider seriously whether or not the presence of these bases was acceptable to the people of

4 Of the 47000 American military personnel based in Japan, 28000 , or 59 per cent are located in Okinawa. Most of these (or around 20000 ) are marines. The American military bases occupy some 235 square kilometres of Okinawan land, representing 10 per cent of the total area of Okinawa Prefecture and about 18 per cent of the main island of Okinawa, which is 67 miles long and 2-18 miles wide. Some 37 US military installations are located in Okinawa, amounting to 75 per cent of all American facilities in Japan, although Okinawa represents 0.6 per cent of the total land area of Japan (see Defense of Japan 1998: 268).

5 Prior to reversion, Okinawa and mainland Japan shared about 50 per cent each of the total number of US bases in Japan (Tanji Miyume, in a personal communication, 25 November 1999, quoting Arasaki Moriteru, Okinawa Sengoshi [A postwar history of Okinawa]). After reversion, the proportion of US bases in Okinawa rose to 75 per cent in spite of the fact that what the Okinawans (according to Governor Ota) 'sincerely wished for at the time of the reversion was a reduction of bases at a rate at least comparable to that experienced on the mainland (hondonami) ('The Text of Governor Ota's Testimony', in JPRI Staff 1997: 4). According to Tanji Miyume, the Sato government repeated that the US military bases in Okinawa would be kaku nuki (no nukes) and hondonami. Personal communication, 25 November 1999. 
Okinawa, but for more than two decades it ignored the suffering and dislocation of Okinawans caused by the bases. Little was done to ameliorate their impact and improve their level of acceptability even by instituting the kind of restrictions that applied to US base operations on the mainland. Differential arrangements governed military activities by US forces in Okinawa, including the failure to restrict US flying hours and the looser restrictions on certain military manoeuvres (JPRI Staff 997: 3). As an editorial in Japan's economic weekly observed,

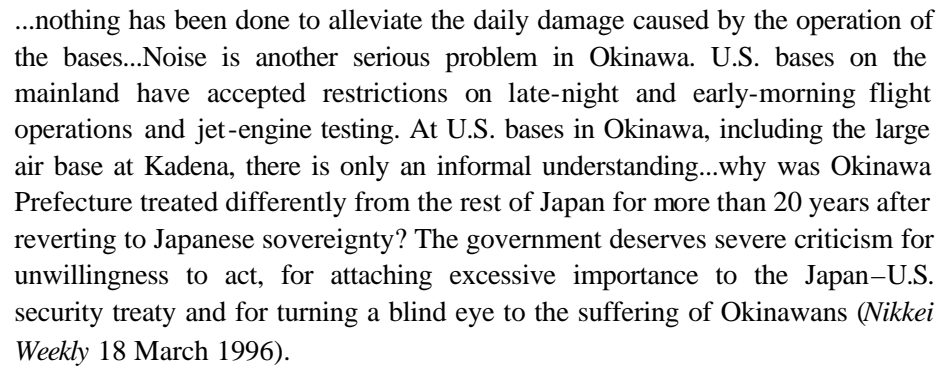

Not surprisingly, much of the resentment of Okinawans is directed towards the central government in Tokyo rather than towards the US government, although there is considerable antagonism towards the US military amongst the localOkinawan communities that play host to the American bases.

\section{Buttressing the powers of the central government against local government}

The Okinawa base issue underscores the political dominance of the centre over the periphery in Japan. The tendency of central government policy to override the local will has continued unabated in Okinawa since the 1870s (JPRI Staff 1997: 4). Whenever local government leaders in Okinawa have thrown down a challenge on base issues, the central government has moved swiftly to assert its predominance by recourse to executive, judicial and legislative action. This perpetuates the dominant historical trend towards the centralisation of authority and the erosion of local autonomy in postwar Japan (McCormack and Sugimoto 1986: 12-13), in spite of the decentralising thrust of the current 'administrative reform' (gyosei kaikaku) program. Indeed, legal controls over matters relating to US bases in Okinawa been have made an explicit exception to the current moves for devolution of power from the centre to the periphery in Japan.

Most obviously, the central government has resorted to the use of judicial, executive and legislative powers to deal with the issue of the compulsory leasing 
of land for US bases in Okinawa. In the wake of the September 1995 rape of the Okinawan schoolgirl, Governor Ota refused in protest to cooperate with the Japanese government in the procedure required by the 1952 Land Acquisition Law made applicable to the US bases by the Special Measures Law for Land Used by the American Forces (Taira 1997: 3). Ota declined to sign documents on behalf of the central government which would allow the continued forced leasing of land for use by the US military.

Ota was not alone in his opposition. Also refusing to sign were leaders of local authorities up to the level of governor, who, under law, can serve as proxies in such cases (Nikkei Weekly 1 April 1996). When a landowner refuses to sign documents sanctioning forced use of land by the central government, the head of the municipality concerned (that is, the local mayor) is required to sign in his or her place. If the mayor also baulks, the task falls to the prefectural governor under the Land Acquisition Law, which requires the prefectural governor acting as the 'promoter of a project' to sign the land leases. If the governor also refuses, he becomes liable to legal action. The prime minister can file a law suit 'requesting' the governor to carry out his duties (Weekend Australian 30 September-1 October 1995).

When Ota declined to sign documents as a proxy for the landlords who were unwilling to renew their leases with the US military, Prime Minister Murayama filed a lawsuit under the Local Autonomy Law requesting a court order for the execution of the forced leasing. This legal action was predicated on the assumption that the refusal of the governor to sign the land leases was an infringement of the so-called 'delegated functions' or 'agency-delegated tasks' (kikan inin jimu) provision in the Local Autonomy Law. ${ }^{6}$ More than 500 laws and ordinances in Japan require local governments to undertake various so-called 'agency-delegated tasks' involving provincial governors and mayors acting as agents of the bureaucracy in Tokyo in implementing central government policy. In undertaking these policy-related tasks, these democratically elected local politicians owe their primary responsibility to the central government, not to those who have voted for them. If necessary local politicians can be compelled

6 As Taira explains: 'The Local Autonomy Law describes prefectures as organs of the state with respect to the execution of certain functions delegated to them by the state. According to [this argument]...the signing of land documents in cases of land taken for U.S. military use was a function delegated to prefectural governors. Therefore Governor Ota's refusal to comply constituted a dereliction of duty and insubordination to the state in violation of the Local Autonomy Law...[This] assumed...a natural link between the governor's role under the Land Acquisition Law and the "delegated function" under the Local Autonomy Law' ( (1997: 3). 
by the courts to carry out their duly designated duties. Persistent failure to do so can result in their enforced removal (see Arase 1998: 2).

Although the central government formally had the responsibility to force unwilling property owners to lease their land to the US military, under the kikan inin jimu system it gave the actual power to do so to local governments. Ota was subsequently ordered by a local district court to execute duties of state delegated to him in relation to enforcing the base leases. For his part,

Governor Ota argued against the connection between delegated State duties under the Local Autonomy Law and cooperation with the forcible acquisition of Okinawa's land for use by the American military (JPRI Staff 1997: 1).

In passing judgement, the Naha branch of the Fukuoka High Court 'avoided the issues of constitutionality and local autonomy and merely asserted that Ota must yield under the Land [Acquisition] Law' (Taira 1997: 4). Undeterred, Ota appealed to the Supreme Court of Japan. In the meantime, in view of Ota's continuing refusal and his appeal to the Supreme Court, Prime Minister Hashimoto (who took over from Murayama in January 1996) exercised his authority to sign the renewed leases just prior to their expiry on 31 March 1996 (Nikkei Weekly 1 April 1996). The prime minister was technically permitted to do so because it was claimed that he was the promoter of the projects (that is, bases) in question under the 1952 Land Acquisition Law (Nikkei Weekly Editorial, 1 April 1996; see also Taira 1997: 3). Prime Minister Hashimoto in fact acted on several occasions to sign renewed base leases in the 1996-97 period in lieu of Governor Ota.

The central government also passed an amendment to the Special Measures Law for Land Used by the American Forces governing US military use of land on Okinawa to make lawful continued use of bases even during renewal negotiations following the expiration of leases. The amendment was enacted in April 1997 in order to prevent American forces from being deemed to be illegally occupying land whose leases were due to expire on 14 May 1997 and while the national and local governments sorted out procedural delays and difficulties with respect to lease renewals. ${ }^{7}$ The law change permitted the US military to continue running twelve facilities on land owned by about 3000 landlords who had refused to renew their leasing contracts. Henceforth the government could continue using land plots for the US military by providing compensation money

7 The Defence Agency described the amendment as 'a minimum necessary measure for temporary use of land...[which] in no way change s the existing rights of prefectural governors and chiefs of cities, towns and villages, as well as prefectural expropriation committees' (Defense Agency 1997: 237). 
to landlords even if it failed to gain their approval for the continued leases (Australian 4 April 1997).

In a more recent development, a government 'administrative reform' committee set up to make recommendations to decentralise government administration (the Committee for Promotion of Decentralisation, an advisory body to the Prime Minister's Office) recommended that local governments should, in future, have no jurisdiction over military base management, because of the importance of these matters to national security (Arase 1998: 5). This recommendation was designed to avoid future delays in lease renewals and to pave the way without interference from local authorities for the construction of a sea-based heliport facility off Nago City to replace the US Marine Corps Air Station (MCAS) Futenma located in the middle of the city of Ginowan.

The recommendations of the decentralisation advisory committee have since found their way into legislation. A law passed in 1999 which will take effect in April 2000, calls for decentralisation of government duties. The bill amends 475 laws including the Local Autonomy Law. It divides national administrative duties into autonomous duties, which a local government can handle at its own discretion, and legally entrusted duties, which are delegated to local governments by the central government (that is, the 'delegated functions' system as at present). About 55 per cent of all national administrative duties passed on to local governments will henceforth be of the autonomous type. The legislation constitutes the most significant decentralisation measure undertaken since the US Occupation of Japan. Significantly, however, it makes an exception for the function of compulsory acquisition of land for US bases, which the central government has taken back from local government. As of April 2000, the central government will assume the duty it previously delegated to local government on this matter.

\section{Constitutional property rights}

One of the major claims of Okinawans is that the constitutional rights to private property of Japanese landowners have been violated by the enforcement of leases of parcels of land for use by US forces. Article 29 of the Constitution states that 'the right to own or to hold property is inviolable'. When Governor Ota refused to sign the documents needed to extend the forced leases of land for US bases in late 1995, he told reporters he was 'going to insist in court that forcing them to renew violates rights of property ownership and land holding 
guaranteed under the Constitution' (Nikkei Weekly 27 November 1995). ${ }^{8}$ His legal team also demanded that the court allow landowners to speak as witnesses, to give them an opportunity to explain how the US military presence was violating Okinawans' constitutional rights. ${ }^{9}$

In his appeal to the Supreme Court that followed, Ota argued amongst other things that forced contracts violated the Japanese Constitution, which protects private property. His appeal contended that the lawsuit implied 'issues of basic human rights such as constitutionally guaranteed property rights, people's rights to a life in peace, and [the prefectures'] rights to home rule' ('The Text of Governor Ota's Testimony', in JPRI 1997: 4). Therefore, the Okinawa base issue was one that impinged on the basic human rights of Japanese nationals everywhere (ibid).

Ota's appeal was lost. In essence, the question of Okinawan landowners' rights comes down to a political rather than a constitutional or legal question, insofar as Article 29 of the Constitution also provides that 'private property may be taken for public use upon just compensation therefore'. This Article embodies the eminent domain powers of the state vis-à-vis private property owners. These powers are implemented through the legal provisions of the 1952 Land Acquisition Law, which gives the state the right to acquire private land for public use.

The law that specifically embodies these eminent domain powers in relation to US bases in Japan is the Special Measures Law for Land Used by the American Forces. Under the law, the government can forcibly acquire title to appropriate land for USFJ facilities when the consent of landowners has not been forthcoming (Defense Agency 1997: 237). ${ }^{10}$ The state's legal rights were,

8 According to Taira, one of the constitutional and legal issues raised in relation to the US bases in Okinawa is the fact that many of the bases occupy land forcibly acquired from their rightful owners by the US military during the early 1950s when Okinawa was under American military occupation. This kind of expropriation would not have been possible under the Japanese Constitution or under Japanese law, hence the argument of the Okinawan anti-base activists that the US bases in Okinawa 'came into being in violation of the Constitution of Japan' (1997: 3).

9 This is despite the fact that when tested in court by a group of Okinawan citizens in 1990 in 'a bid to overturn on constitutional grounds expropriation of property for American military bases...the Naha District Court held such seizure to be in accordance with the Constitution' (Stockwin 1999: 172).

10 According to Governor Ota, under the US-Japan Status of Forces Agreement, 'Article 2, permits military bases to be built in any area of Japan under the authority of the Mutual Security Treaty' ('The Text of Governor Ota's Testimony', JPRI 1997: 4). In fact Article II states: 'The United States is granted, under article VI of the Treaty of Mutual Cooperation and Security, the use of facilities and areas in Japan' (United States 
therefore, used to override local landowners' refusal to sign renewals of land leases.

In this respect, Japan differs little from most other democratic governments which subordinate individual property rights to the needs of the state and its definition of the national interest. Eminent domain powers are regularly exercised by governments to acquire land to build roads, railways and government facilities such as military bases-providing, of course, that due process is followed and compensation is paid. In a democracy, the chief sanction against the exercise of such a right is political, not constitutional or legal. From this perspective, the Japanese government's actions appear somewhat arbitrary and highhanded, given its scant regard for the preferences and objections of the landowners concerned and its 'non-negotiable' stance on the issue. ${ }^{11}$ However, given that providing bases for US forces is Japan's only obligation to the United States under Article 6 of the Treaty of Mutual Cooperation and Security, the government attaches a great deal of importance to it.

\section{The judicial system as a tool of the Executive Branch}

The judicial system has been used as an instrument of coercion by the Japanese government much more successfully than as an instrument of protesting landowners and their political supporters on base leasing issues. The anti-base forces have failed in their bid to use the courts as a means of redress for their grievances.

This failure contrasts with the patent successes of Japanese citizens' movements in the 1960s and 1970s in obtaining favourable court judgements against private polluters in a series of landmark cases. These judgements forced the hand of the bureaucrats and the ruling LDP who subsequently enacted antipollution legislation. A key difference between the two sets of cases is that the defendants were private companies in the pollution cases, whereas in the Okinawa base leasing cases, the protagonist has been the state.

The Japanese Supreme Court has a consistent record of conservative bias against anti-establishment causes and against individuals challenging state

Forces Japan, 'Agreement Under Article VI of the Treaty of Mutual Cooperation and Security Between the United States of America and Japan, Regarding Facilities and Areas and the Status of United States Armed Forces in Japan'), at http://www.yokota.af.mil/usfj/SOFA.htm

11 Part of the problem is practical. US bases in Okinawa are, in large proportion, made up of many small parcels of privately owned land, which would make it impossible for some landowners to agree to lease their land for base purposes and some not. 
authority or state policy (see, for example, the critique in Nomura 1987). It supports the maintenance of public order and rules in favour of laws and regulations that circumscribe individuals' rights against the state (van Wolferen 1989: 198). It is widely evaluated as the most conservative of all the courts in Japan and has been known to reverse more liberal decisions of lower courts (Nomura 1987: 144-5).

The Supreme Court's conservative bias is particularly evident in relation to its function of judicial review which it is granted under Article 81 of the Constitution. As Stockwin observes (1982: 213),

...the Supreme Court has been cautious and conservative for the most part in handling its newly found power of judicial review and in defending constitutional provisions against administrative erosion

In the entire postwar period, 'the Japanese Supreme Court has rarely held a statute unconstitutional' (Ramseyer and Rosenbluth 1993: 150).

Supreme Court judgements on issues involving Japanese security policy invariably support the government's position. Japanese legal experts claim that 'the judicial branch in Japan, especially the Supreme Court, has traditionally supported the executive branch on important issues surrounding the country's defense or security policy' (Nikkei Weekly 11 August 1996). Most significantly, the Supreme Court's failure to support a literal interpretation of Article 9 of the Constitution - the Peace clause-has effectively enabled Japan to build up potent armed forces and maintain the world's third largest defence budget.

On security matters, the Supreme Court has absolved itself from its constitutional review function by arguing that the matter constitutes a 'political question'. ${ }^{12}$ These cases have on occasions involved matters relating to US bases in Japan. In the much publicised Su nakawa case of $1959,{ }^{13}$ which ruled on the matter of trespass by Japanese demonstrators on the US air base at Tachikawa, the Supreme Court abrogated its right of judicial review by holding that the matter was a 'political question' and thus beyond its jurisdiction, overturning the Tokyo District Court ruling that had acquitted the defendants on the grounds that the US-Japan Security Treaty was unconstitutional under Article 9.

12 According to Stockwin: 'Cases have been brought before the courts where the peace clause has been at issue. In a number of cases the Supreme Court has been reluctant to declare unconstitutionality where it judges that what is at stake is a "political question". (Stockwin 1999: 171).

13 This was first to involve Article 9 directly (Stockwin 1999: 171). 
Subsequently the Supreme Court managed to avoid the issue of constitutionality on several matters brought before it relating to both Japanese and American bases (Stockwin 1999: 172). In February 1983, for example, the Supreme Court ruled that the Japanese government should compensate residents for the noise caused by US aircraft at Yokota Air Base just west of Tokyo, 'but rejected demands for a ban on night flights, stating that U.S. military activities are beyond the jurisdiction of the Japanese government' Nikkei Weekly 20 May 1996).

The Supreme Court's ruling in August 1996 on the Ota appeal did not deviate from these judicial precedents. The question was whether it was legal for the central government to compel Ota to sign documents needed to expropriate land for use by the US military. The Supreme Court dismissed the appeal and upheld the lower-court decision. It ruled that the special law legalising the expropriation of private land by the government for the use of the US military was 'not unconstitutional' and that Ota's refusal to sign the necessary documents on behalf of the government 'harmed the public interest' (quoted in Nikkei Weekly 2 September 1996). The decision ordered Ota to sign documents so that the central government could renew its lease contracts with local landowners. The leased land could then be used by the US military. As Taira points out (1997: 4):

Both the Fukuoka High Court and the Supreme Court essentially said that Japan's treaties and agreements with the United States were constitutionally valid and that the courts had no jurisdiction over the 'high political decision' that resulted in stationing U.S. military forces in Japan. With this judgement, the Japanese Supreme Court sustained its reputation for excessive conservatism and minimalism in the use of its prerogatives.

Most informed observers at the time expected the court to uphold the lower court decision and rule that procedures taken by the central government to allow continued use of land by the United States were constitutional. According to a Japanese media report, this was because the court was 'known for being conservative and supportive of the government' (Nikkei Weekly 11 August 1996). In particular, the Supreme Court Chief Justice Tooru Miyoshi was said by many 'to lean toward conservative rulings, as did his predecessors' (ibid).

The Supreme Court's decision was issued after a short sitting (only three months), considerably shorter than the time it usually took to make such rulings. For example, it took two years and four months to review the Lockheed bribery case that involved former Prime Minister Kakuei Tanaka before handing down a ruling Nikkei Weekly 11 August 1996). Moreover, it rarely handed down a decision in August because most of the judges normally took their summer 
holidays at that time. Many legal experts accused the Supreme Court of dealing with the Ota appeal in a rapid fashion to help the central government get rid of its troubles in Okinawa as soon as possible. The attorney representing Ota said: 'This trial is extremely unusual in every aspect', particularly the ruling after only three months. The Secretary-General of Ota's political support group, a lawyer and Upper House politician commented that: 'It is absolutely nonsensical to most of us lawyers that the Supreme Court hands down a decision in such a short period' (ibid). Eldridge also reported that the timing of the verdict just prior to the crucial base referendum in Okinawa in September 1996

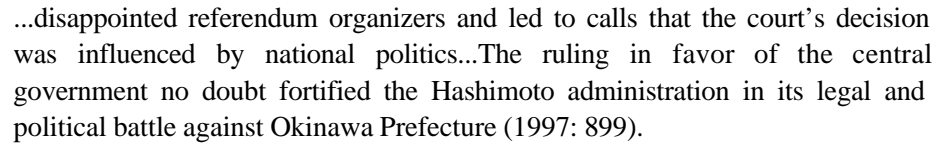

Similar criticisms with respect to the timing of the court's ruling were also levelled at the Presiding Judge of the Naha branch of the Fukuoka High Court who rushed his verdict against Ota in response to central government's urging that the case be concluded quickly. The urgency for judgement was due to the fact that some 35 base leases were due to expire at the end of March 1996. The judge issued the court order for Ota to sign the base lease renewals on 25 March, ruling that withholding the signature 'was significantly to the detriment of the public interest' (Nikkei Weekly 1 April 1996). ${ }^{14}$ Moreover, the judge decided to end the hearings in response to the central government's call that the court should only discuss the procedural aspects of the governor's refusal, which meant that the landowners' views in question were not heard. The judge's decision was described as inevitable (that is, as politically informed) '[c]onsidering the realities of the U.S. military presence in Okinawa' (Nikkei Weekly Editorial, 1 April 1996).

The way in which the Supreme Court and the Fukuoka High Court handled the respective Ota cases and the method of the courts' rulings underline arguments made elsewhere that the judiciary are a tool of executive branch, especially on matters that embody a challenge to state policy and authority. ${ }^{15} \mathrm{It}$ is not an instrument of radical reform, either on matters of judicial review or on

14 The ruling against Ota was also a foregone conclusion because under the existing law, 'a prefectural governor cannot dispute a forced authorization made by a prime minister on such grounds' (Nikkei Weekly Editorial, 1 April 1996).

15 This point has been made even more critically elsewhere: 'The Supreme Court ruling on the issue signalled that it is a mere tool of the Tokyo politicians and is willing to rubberstamp the confiscation of private property in Japan whenever the central government deems it desirable' (JPRI Staff 1996: 1). 
matters relating to the protection of individual rights against arbitrary acts by the state.

Lack of judicial independence stems from the political controls over judicial appointments and other aspects of judges' employment such as promotions and salary (see Ramseyer and Rosenbluth 1993: 152-60). The Chief Justice of the Supreme Court is designated by the Cabinet and appointed by the Emperor while the fourteen other justices are appointed by the Cabinet (15 justices in all) (Nikkei Weekly 11 August 1996). As the Japanese economic press points out, Supreme Court justices are inevitably conservative, establishment figures because 'the Liberal Democratic Party has controlled the cabinet for most of the postwar era, and the cabinet controls the judicial selection process' (ibid). LDP leaders 'appoint to the Supreme Court only those judges whose policies are consistent with their own' (Ramseyer and Rosenbluth 1993: 152). Nor surprisingly, judges of the Supreme Court are cognisant of LDP policy preferences when deciding cases (ibid: 144). ${ }^{16}$

The cabinet also 'appoints lower-court judges from a list of nominees prepared by the Supreme Court and Secretariat [the administrative offices attached to the Supreme Court]' (Ramseyer and Rosenbluth 1993: 153). According to Ramseyer and Rosenbluth: 'They assign their Supreme Court appointees the job of monitoring the performance of lower-court judges, and of rewarding and punishing them appropriately...Party leaders appoint to the lower courts only those people whom their Supreme Court nominees...recommend to them as appropriate' (1993: 153). ${ }^{17}$ They conclude that: 'In effect, LDP leaders appoint to the apex of the judiciary only those who are politically reliable, and then designate those justices the monitors for the rest of the judiciary' (ibid: 14).

Judicial independence in Japan is nominal rather than real. ${ }^{18}$ The way in which the court system operates sometimes transgresses one of the basic

16 Moreover, the power of the political executive over the judicial appointments process is buttressed by the archly conservative Ministry of Justice which thoroughly infiltrates the Supreme Court's Secretariat, which in turns exerts de facto administrative influence over judicial appointments and acts as gatekeeper to the Legal Research Training Institute, 'through which all those aspiring to become judges, prosecutors or lawyers [in the career judiciary] must pass' (van Wolferen 1989: 214).

17 Ramseyer and Rosenbluth elaborate the various ways in which the ruling LDP manipulates the judiciary in order to reduce 'agency slack' (rational choice parlance for judicial independence) (see 1993: chapters 8 and 9).

18 For example, in April 1996, a group of more than 3000 residents near Yokota Air Base filed suit in the Tokyo District Court demanding that the Japanese and US governments reduce night flights at Yokota and pay a total of $¥ 3.3$ billion in damages for aircraft noise. This marked the first time that the US government was included as a defendant. 
principles of democratic government laid down by the Supreme Court itself: 'that the three powers [that is, judicial, legislative and executive] are independent, equal, and immune from each other's interference'. ${ }^{19}$

\section{Compensation politics}

While lawsuits and special laws have been the 'sticks' in the central government's Okinawan base strategy, the 'carrots' have been subsidies and other economic benefits and incentives allocated to Okinawa not only to compensate it in a generalised way for the over-concentration of American bases in the prefecture, but also to persuade local communities to comply with central government plans for resolving particular base issues and, at the individual level, to encourage landowners to continue leasing their land for US bases. Okinawa provides many such examples of classic 'compensation politics' at work. $^{20}$

In general terms, compensation politics is a government strategy for inducing specific communities, groups and individuals to accept large-scale public works projects with potentially deleterious social and environmental consequences. Compensation involves the distribution of various kinds of material benefits to the locality most affected by the proposed development. Even where the state has eminent-domain powers, it still has to deploy 'compensation instruments to negotiate siting deals with local community interests' (Lesbirel 1998: 32). ${ }^{21}$ The reasons are political. Compensation

According to a report in the Japanese press at the time: 'An official at the Japanese Foreign Ministry's Japan-U.S. security treaty division said that the ministry is discussing with the Justice Ministry how to cope with the latest suit' (Nikkei Weekly 20 May 1996). This comment also raises serious questions about bureaucratic interference from the Justice Ministry in court judgements.

19 A quote from the Supreme Court ruling in the Suzuki case of 1952, a translated version of which appeared in Maki (1964).

20 Compensation is a somewhat misused term in the literature on Japanese politics. Calder, for example, uses it as the principal causal variable in an extended historical explanation of public policy trends in various domestic non-traded sectors in the postwar period. He details a crisis and compensation dynamic whereby the ruling party (principally the LDP) sought to shore up its electoral performance by resorting to the outlay of various material benefits and other concessions to its principal supporting groups over the period 1949-1986. What he was discussing is more accurately described as 'pork barrelling', 'political strategic distributive politics' or 'patronage politics' (see Calder, 1988: especially 36-230).

21 Lesbirel examined private sector compensation to various local interests associated with the installation of energy facilities, principally nuclear power stations. Nevertheless, siting deals can also apply to government-funded public works projects. 
smoothes the path for the proposed developments amongst the locals. By gaining their acquiescence, it lowers the level of disputation and political costs associated with such projects.

Research suggests that local communities in Japan exercise considerable influence over siting outcomes ranging from outright veto to timing delays and plan modifications resulting in risk mitigation. In almost all cases, the sponsors of facilities are required to bargain with and compensate local interests if these projects are to proceed. ${ }^{22}$

When it comes to the US military bases, the government is like a developer who is obliged to pay compensation to local communities for the imposition of base spillover effects (Lesbirel 1998: 32). Private sector companies are also forced to bargain and negotiate with groups of citizens in the course of locating facilities like nuclear power stations with potentially harmful environmental consequences. The Okinawa base issue has many parallels with siting disputes elsewhere in Japan where serious local objections have been raised and against which local interests and citizens have mobilised. In the literature on the siting of energy facilities in Japan, compensation is a standard mechanism used by private companies for dealing with dispute resolution. ${ }^{23}$ In compensation politics, the government resorts to subsidies and other kinds of material incentives as a similar facilitation or mediation mechanism.

Compensation has both positive and negative aspects. It can be used as an incentive for compliance with the government's wishes, or as an instrument of sanction, intimidation and coercion when withdrawal of benefits is threatened. In both cases, compensation acts as a form of 'soft coercion' in order to obtain the desired agreement with government objectives and measures. Compensation has the advantage of not being as patently authoritarian as laws and orders, although ultimately it has a simila r effect when used in this way (Hirose 1981: 6).

Compensation politics in the Okinawan context literally means buying off the opposition to US military bases with various kinds of benefits to local communities. As already noted, this kind of compensation $h$ as been utilised on a prefecture-wide basis in order to engender greater tolerance amongst the Okinawan community to the US bases for much of the post-1972 period. The Okinawans are literally compensated for having to put up with such a concentrated Americ an military presence in their midst. Budgetary subsidies for 'development' programs on the islands including land improvement and road,

22 See the case studies of energy facility siting disputes in Lesbirel 1998: 61-134.

23 As Lesbirel notes, in the literature on Japanese politics, compensation is treated 'as a major conflict resolution mechanism in Japan' (1998: 9). 
dam, port, industrial and tourist projects have been repeatedly used to quell the complaints of Okinawans about the 'inconvenience' caused by the presence of US bases and troops.

Moreover, if one is to believe those who maintain that the presence of the bases is an economic minus for the local economy, ${ }^{24}$ because it stunts efforts to promote local industries and develop local entrepreneurship (Nikkei Weekly 8 January 1996), then subsidies from Tokyo are a double compensation for both the social dislocation the US bases cause and for their specific economic sideeffects. Although many Okinawans may not necessarily be seeking economic compensation-indeed, they may be looking for other forms of redress for their grievances, such as mitigation or elimination of the noxious side-effects of base sites (or even their removal altogether)-they may become the targets of monetary -based substitution strategies, given the government's unwillingness to yield to their principal demands.

Prior to the reversion of Okinawa to Japan in May 1972, the central government passed the Okinawa Promotion and Development Special Measures Law (Okinawa Shinko Kaihatsu Tokubetsu Sochiho), to provide a legal framework for the allocation of central government subsidies for developing the social and economic infrastructure of the island. It also established the Okinawa Development Agency (Okinawa Kaihatsucho) as the administering body of government grants to the prefecture. Subsidies are allocated in the national budget for public education, public housing, public health and welfare, city parks, and public works of all kinds such as coastal works (kaigan jigyo), fishing ports and villages adjustment (gyoko gyoson seibi), sewage works (gesuido jigyo), agricultural production base adjustment works (nogyo seisan kiban seibi jigyo), rural adjustment works (noson seibi jigyo), agricultural land preservation management works (nochito hozen kanri jigyo), forestry environment adjustment works (shinrin kankyo seibi jigyo) and so on (Zaisei, ed. 1998: 42-58). Many of these subsidies are allocated under the provisions of the 1971 Okinawa Promotion and Development Special Measures Law (Okinawa Shinko Kaihatsu Tokubetsu Sochiho). Between 1972 and the mid-1990s, Okinawa saw three 10-year Okinawa promotion and development plans with a total of $¥ 4.294$ trillion allocated for constructing and maintaining the prefecture's infrastructure ('The Text of Governor Ota's Testimony', in JPRI Staff 1997: 2; Sakurada 1998: 27),

24 One of the arguments used by Ota and other Okinawan officials in arguing for increased economic assistance is that Okinawa lags behind other prefectures in economic development because commercially valued lands are occupied by the US military (Nikkei Weekly 2 September 1996). 
while some 78 per cent of the prefectural government's budget derives from central government subsidies (Sakurada 1998: 27).

The scale and focus of central government subsidies to the prefecture represent not only the application of classic pork barrel-style politics that is endemic on the mainland, but they have the added compensation dimension because of the US bases. The Okinawans are particularly vulnerable to the need for financial support to develop industries other than tourism, which is the No. 1 industry in Okinawa ${ }^{25}$ apart from the subsidy-dependent public works industry, which disseminates the benefits of public works subsidies to local construction companies and their employees. The towns and cities in which US bases are located also receive specific 'host town compensation support from the national government' (Eldridge 1997: 897). In addition, Okinawa benefits from the Japanese government's omoiyari yosan ('sympathy' budget) payments to the United States for the costs of running the bases in the form of rents to landlords who lease land to the US military, and the wages of those civilian Japanese who are employed on the bases or who provide various services to them. ${ }^{26}$

Since late 1995 and the rape of an Okinawan schoolgirl by three American servicemen, one solution to the Okinawa problem for the central government has been to try and resolve the base issue with liberal transfusions of money in the form of subsidy and other economic benefits and development incentives to the people of Okinawa (McCormack 1998: 7). The government has ratcheted up compensation from the national budget in order to deal with the surge in popular resentment against the US bases in Okinawa, ${ }^{27}$ and as a supplementary strategy

25 In 1997, tourism generated $¥ 417$ billion in income for Okinawa (Asahi Evening News 11 August 1999).

26 Mike Millard claims that more than 8000 Okinawans are employed on US bases, and 'many thousands more are employed in the entertainment and service industries around those installations' (1998: 4). Figures vary, however, with respect to the dependence of the Okinawan economy on the US bases. According to Patrick Smith, 25 years ago, the bases contributed almost 20 per cent of the Okinawan economy but these days it is less than 5 per cent (1998: 2). Ralph Cossa, on the other hand, advances a somewhat more inflated figure, arguing that annual base-related revenue is over $¥ 1.5$ trillion (US\$15 billion) a year, accounting for over 10 per cent of the entire prefecture's total income (1996). Sakurada's figures for annual base-related revenue are much lower. He maintains that 'Okinawa receives a total of approximately $¥ 183$ billion annually as revenue from the US bases in Okinawa, and the bases offer lucrative jobs to the local residents, employing 23,000 people' (1998: 27). The basis on which he calculated the latter figure is unknown.

27 Spending relating to Okinawa (categorised as Okinawa-related expenses in the government’s General Account— that is, main — budget) jumped from $¥ 465$ billion in 1994 , to $¥ 483$ billion in 1995 , $¥ 520$ billion in 1996 , $¥ 521$ billion in 1997 , $¥ 679$ billion in 1998 (that is, by over ¥200 billion in the 1995-98 period, or 41 per cent, 
to other measures adopted by the Japanese and US governments. ${ }^{28}$ According to budget documents, the expenditure has been

...for the provision of education, the development of the industrial economy, and consolidation of social capital in order to achieve an improvement in the welfare the stabilisation of the standard of living of the Okinawan people (Zaisei Kinyu Tokei Geppo 1997, No. 541, May: 87).

Special allocations have been also used as a negotiating tool on specific base-related issues. Ota's obdurate refusal to sign documents involved in lease renewal elicited specific offers of compensation as an inducement to compliance. In the midst of the negotiations and legal brouhaha over the signing of land leases, the central government decided to increase spending in Okinawa. In August 1996, it tried to win Ota's cooperation on lease renewal by considering a hefty package of economic privileges for the prefecture. Prime Minister Hashimoto said he would consult the governor on the details of the latter's request for free-trade zones, new port facilities, relaxation of tourist visa rules and investment incentives to boost the Okinawan economy Australian 20 August 1996). In fact, '[g]overnment officials were frank...in admitting the development plan was aimed at persuading Mr Ota to co-operate' (ibid).

In the same month, the Chief Cabinet Secretary sponsored for the first time an 'informal meeting on Okinawa municipalities hosting US bases' which aimed to discuss development in the cities and towns hosting US bases. According to the Japanese Defence White Paper:

A follow-up meeting...adopted a proposal that...called for an implementation of a special project aimed at alleviating the feeling of repression amongst Okinawa municipalities hosting U.S. bases and exploring the possibilities of their selfsupporting development in the future (Defense Agency 1997: 234).

In September 1996 a milestone meeting took place between Hashimoto and Ota. At the meeting, the prime minister pledged to reduce the bases in Okinawa and to implement measures to promote the local economy so that it would be less dependent on income from the bases. He presented a plan to allocate $¥ 5$ billion to Okinawa as quickly as possible to help develop industry, trade and

which was well above the rate of increase in the overall budget at 3.8), and $¥ 537$ billion in 1999. These figures were calculated from budgetary figures in Zaisei Kinyu Tokei Geppo (various issues). The 1999 budget included a special allocation of $¥ 5$ billion as necessary expenses for the promotion of special promotion and development works based on the Okinawa Promotion and Development Special Measures Law 'for the effective development of Okinawa promotion policy in view of the serious economic conditions in Okinawa' (Zaisei Kinyu Tokei Geppo 1999, No. 565, May: 93). 
tourism in the prefecture. It was aimed at benefiting local mayors who supported the bases and their towns (Patterson 1996). One observer remarked that 'Hashimoto asked Ota to accept the current situation surrounding Okinawa by offering him economic assistance' (Nikkei Weekly Editorial, 16 September 1996), although a Nikkei Weekly editorial also commented that 'measures for economic promotion of Okinawa should never be an attempt to resolve the base issue with money' (2 September 1996).

Hashimoto also promised to form a special team consisting of the Chief Cabinet Secretary, other cabinet members and Governor Ota to formulate policies to reduce the US military presence in Okinawa and promote economic development. Following the meeting with Hashimoto, Ota announced that:

The prefecture's demands have been considered earnestly, and the wishes of the prefectural government and the business community have been incorporated almost in their entirety. If the items the prime minister talked about are acted upon with budgetary backing, it seems to me that the future [of Okinawa] looks much brighter (Eldridge 1997: 902).

Following his September 1996 meeting with Hashimoto, Ota also agreed to sign the documents for the forced leases. ${ }^{29}$ Although he personally still refused directly to sign documents that would allow the US military to keep using land that individual owners wanted to take back, the governor said he would prepare a public paper detailing the central government's request for continued use. The paper was needed for Hashimoto to sign the documents that would expropriate the land for a new lease period. Ota claimed that it was the hardest decision he had made in the previous six years.

The Okinawa Policy Council was subsequently established as

...a consultative body between the central government and Okinawa Prefecture chaired by the chief Cabinet secretary to discuss a [sic] basic policies on Okinawa. The council will see to it that the quality-of-life in Okinawa prefecture will be improved under the current situation of USFJ facilities and areas, and that Okinawa Prefecture will be rebuilt as a region contributing to Japan's socioeconomic development. The council has subcommittees on social capital, industry and economy, and environment, technology and international exchanges. Each subcommittee has set up project teams, which have been pushing for consultations (Defense Agency 1997: 234).

29 Although Ota still refused to directly sign documents that would allow the US military to keep using land that individual owners wanted to take back, the governor said he would prepare a public paper detailing the central government's request for continued use. The paper was needed for Hashimoto to sign the documents, which in effect would expropriate the land for a new lease perio d (Nikkei Weekly 16 September 1996). 
The ten project teams consisted of officials from relevant government bodies and Okinawa to work for measures to promote the economic development of Okinawa.

Compensation politics has been the chief strategy of the central government in its handling of the dispute over the relocation of MCAS Futenma which has remained an active siting dispute since 1996. In late 1997, when the contro versy surrounding plans to build an offshore heliport off Nago in Northern Okinawa appeared to be coming to a head, and with a referendum due to be held in Nago in December 1997 on whether city residents wanted the planned heliport to proceed, the Hashimoto government pushed to win support for its heliport plan by linking it to economic development initiatives (Nikkei Weekly 22 September 1997). The Defence Agency task force set up to deal with the relocation of Futenma Air Station had its first meeting on 4 September 1997 and resolved to consider economic development plans in conjunction with a coordinated interministry effort to win Okinawan approval for the offshore heliport. ${ }^{30}$ According to observers, the initiative stemmed from Tokyo's growing impatience with local opposition to the heliport plan. A rough plan for the heliport was packaged with economic development proposals, which included expansion of the Okinawan free trade zone, tax breaks for companies, deregulation, and subsidies to promote selected industries, including tourism (Nikkei Weekly 8 February 1998). The plan was to include appropriations in the budget proposal for fiscal 1998 (Nikkei Weekly 22 September 1997). It assumed construction of the floating heliport in Nago. In short, one part of the deal was contingent on the other (Nikkei Weekly 15 December 1997).

For the residents of Nago who were due to vote in the referendum, it boiled down to a classic choice between central government-sponsored, subsidydriven 'development' combined with the floating heliport on the one hand, and no base, environmental preservation and possible loss of fishing grounds on the other. The proposition put to the local residents contained unadulterated economic incentives - accept the heliport in exchange for economic stimulus measures (Nikkei Weekly 15 December, 1997). According to Millard, the LDP 'pulled out all the stops' in the weeks leading up to the Nago referendum on the proposed heliport,

30 The floating heliport would have been a budgetary windfall for the Defence Agency. It planned to add about $¥ 2$ billion to its fiscal 1998 budget as research expenses in connection with its construction (Nikkei Weekly 29 December 1997-95 January 1998). 
...canvassing the area and promising residents that their economic interests would be served by the base, that its dangers and problems would be few, and claiming that it was needed for the defense of Japan by American forces (Millard 1998: 4).

The government was seeking to manipulate the economic self-interest of local businesses hoping for greater patronage, but particularly local construction contractors, dependent on government-subsidised public works for a living. ${ }^{31}$ As one resident of Nago commented, instead of development and the bases being separate issues as the LDP always maintained, clearly the politicians 'are trying to trade the base for development' (Nikkei Weekly 15 December 1997). Even the wording of one of the affirmation statements in the referendum contained an explicit 'compensation' assumption: 'I agree (with building the heliport) because promised anti-pollution and economic measures can benefit the community' (Miyagi 1998: 2)

In spite of the economic inducements, the central government's efforts to bring the Nago community into line showed no results (Nikkei Weekly 9 November 1998). A majority of Nago voters rejected the proposed heliport followed by an open declaration of opposition from Ota to the heliport plan during the mayoral election in the city in February 1998. Ota's action infuriated the LDP and elicited threats of retaliation against the prefecture (Miyagi 1998: 2). Ota's dialogue with Prime Minister Hashimoto was severed and never reestablished (Mainichi Daily News 1 September 1998). A Defence Agency official, frustrated with Ota's lack of support for the floating heliport, accused him of acting spoiled. He said: 'We've given him economic promotional measures and everything possible' (Nikkei Weekly 26 January 1998). The LDP's Okinawa branch and local industrial circles warned that 'Tokyo would lose enthusiasm for pouring money into the flaccid Okinawan economy' (ibid). The upshot was that the central government withdrew part of its planned $¥ 5$ billion in public works projects as a retaliatory measure against Ota's obstinacy Asahi News 16 November 1998).

However, as soon as a candidate sympathetic to the Nago heliport won the mayoral election, the administration, its anger assuaged, 'again dangled its main carrot and decided to submit a bill for promoting economic development in Okinawa to the...Die t' (Nikkei Weekly 16 February 1998). The decision on the heliport was up to the Tokyo government and the Okinawa prefectural

31 One construction company owner said, 'Construction of the heliport is a golden opportunity for revitalization of the town', adding that 'We will go bankrupt if the situation doesn't change. The package will lead to prosperity in all of northern Okinawa' (Nikkei Weekly 15 December 1997). 
government, but the mayoral election in Nago gave the central government hope that Ota would change his mind. According to a Defence Agency official: 'The election result has given Ota a window of opportunity' (ibid). To no avail: economic blandishments aside, this was an opportunity Ota obstinately refused to take.

In the November 1998 gubernatorial election in Okinawa, Ota lost to Inamine Keiichi, a pro-development, local business leader, ${ }^{32}$ who was a member of the LDP. In his campaign, Inamine emulated a favourite LDP technique of turning 'the financial vulnerability of local government to partisan advantage by arguing that the LDP's pipeline to the center would keep the local community supplied with development projects and subsidies' (McKean 1981: 253). As Jameson observed: 'Mindful of how important national subsidies are to the Okinawa economy, voters ousted Ota and chose as governor a former businessman who promised to improve ties with Tokyo' (1998: 82). Inamine displayed a willingness to cooperate with the government over the base issue by pledging the relocation of the US marine air base to an unspecified location in northern Okinawa. He held out an economic carrot himself in proposing that the new airstrip be built for both military and civilian use. The economy was rated the top election issue by 51 per cent of voters, compared with 25 per cent for the US bases-in circumstances where unemployment was 9.2 per cent compared with the national average of 4.3 per cent (Australian 12 November 1998).

More importantly, Inamine stressed the need for open communication channels with the central government and the importance of flexible negotiations and compromise 'for the sake of economic development' (Smith 1998: 2). He accused Ota of creating a 'gubernatorial recession' by fiercely rejecting the central government's plan to construct an offshore heliport near Nago (Asahi News 16 November 1998). He said: 'I want to steadily put in place a number of stimulus measures, by building up a relationship of mutual trust with the government' (Nikkei Weekly 14 December 1998). His election platform promised 'economic development with the central government' (Asahi News 16 November 1998). In his campaign speeches, he claimed that he would put 'the negotiations with the central government on track by temporarily accepting the relocation of bases within Okinawa and accepting money from Tokyo' (ibid).

In contrast to Ota who put the base issue as the No. 1 item on his negotiating agenda with Tokyo, Inamine, although not a base supporter, was prepared to lower the level of aggravation on the matter of relocating Futenma.

32 Inamine was former President of Okinawa Management Organisation and special adviser to a prefectural business leaders' association. 
Furthermore, he campaigned on his potential to manipulate his Tokyo connections for Okinawa's economic advantage (Smith 1999: 198). Ota, on the other hand, was widely admired for his stance on the bases, but many locals felt, given Okinawa's weak economy, that he was standing between them and the badly needed billions promised by Tokyo (Nikkei Weekly 16 February 1998).

In the final analysis, the economic self-interests of voters won out over principle. The Japanese recession had begun to bite into the Okinawan economy, and voters were worried about Ota's exclusion from the corridors of influence in Tokyo (Smith 1999: 198). The election came down to a trade-off between bases and subsidies, the two most important items on the politicoeconomic agenda in Okinawa. Inamine's electoral advantage was based primarily on his better positioning in the subsidy stakes, illustrating how deeply entrenched subsidy-driven politics distorts the electoral process in Japan. Inamine's victory was also testimony to Okinawans' anxieties about Japan's economic recession and the even worse economic climate in their prefecture. For the time being, the prefecture's heightened economic dependence on central government overrode antibase sentiments. Professor Gabe Masaaki of the University of the Ryukyus, however, claimed that: 'Because Inamine won, the government may consider that money can solve the problems. However, that will only be the case during the economic recession. Discontent with the bases remains' (Nikkei Weekly 23 November 1998).

With the inauguration of Okinawa's new governor, the central and prefectural governments set about their two main tasks: getting the teetering local economy back on its feet and ending the controversy surrounding the Futenma relocation issue. The Chief Cabinet Secretary, Nonaka Hiromu, said that the government would temporarily place greater priority on easing economic woes in Okinawa and put the base issue on the back burner (Nikkei Weekly 7 December 1998). The central government also agreed to restart the deadlocked Okinawa Policy Council, whose deliberations had been suspended for about a year because Ota had rejected relocation plans for Futenma (Nikkei Weekly 14 December 1998). The council discussed emergency measures to create jobs and support local businesses as well as medium to long-term projects such as infrastructure investment. At the meeting held in mid-December 1998, Prime Minister Obuchi Keizo announced an appropriation of $¥ 10$ billion for special stimulus measures for Okinawa from the draft budget for fiscal 1999 (ibid). Prior to his election, Inamine had requested six emergency measures for recovery, including help in inviting companies to the prefecture's Free Trade Zone (ibid). As the Nikkei reported: 
The improved relationship between the central government saw $¥ 10$ billion ( $\$ 82$ million) allocated specifically for the prefecture, and the Nakagusuku Bay Port development area near the central part of the Okinawa main island was designated as a special free-trade zone. In addition, the central government announced plans to boost the prefecture's economy by setting up an information-technology and tourism-promotion zone in the prefecture' (Nikkei Weekly 7 June 1999).

In June 1999, the Okinawa Policy Council produced an interim report, the 'Okinawa Economic Promotion Plan for the 21st Century' which included as a 'key project' the construction of a special international communications zone in Okinawa with the idea of turning Okinawa into a special communications hub for the Asia-Pacific. A study group jointly established by the Ministry of Posts and Telecommunications, the Okinawa Development Agency and the Okinawa prefectural government and comprising members of the government, industrial and academic sectors "will study ways to attract communications and information technology companies...to the prefecture, as well as measures to boost employment' (Daily YomiuriOnline 1 September 1999).

The decision to host the Group of Eight (G-8) summit in Nago in July 2000 is yet another gesture to shore up the prefectural economy and to appease Okinawan sentiment over the Futenma relocation issue. The idea in fact originated from Governor Inamine. The decision has reputedly raised locals' expectations of economic growth centring on the information-technology and tourism industries (Nikkei Weekly7 June 1999). As the Mainichi commented:

The central government officially denies a direct connection between the transfer of the Futenma Air Station and the G8 summit, but there is no doubt that the government hopes to use the summit as a lever to facilitate a solution to the Futenma problem (Mainichi Daily News 7 September 1999).

Many analysts have questioned this style of compensation politics. Firstly, it is argued that 'the best way to help Okinawa become independent economically is to reduce US bases as much as possible...[because it] is US bases that have been preventing Okinawa from developing' (Nikkei Weekly 22 July 1996).

Therefore, outlaying fiscal assistance to perpetuate the bases is a bad idea.

Secondly, this approach (particularly in relation to the Futenma relocation issue but also with respect to Okinawa Prefecture more generally) exemplifies the poverty of a formula that combines bases and development, which represents the worst of all worlds if it entails mainland style development which is environmentally inappropriate in Okinawa (McCormack 1998: 3). More infrastructure investment will just compound the environmentally destructive 
impact of this style of development on Okinawa to date (ibid). As McCormack observes, Okinawa has suffered the imposition over its 'delicate coral and subtropical forest environment [of] the same public works practices and the same collusive structures of mainland Japan's "construction state".'(ibid). Infrastructure projects have primarily benefited the large numbers of small construction contractors in Okinawa (and their employees) who undertake at great profit the various government-sponsored public works projects in question. In this way, Okinawa has been subjected to the twin destructive elements of US military occupation and Japanese-style development (McCormack 1998: 2).

Thirdly, research suggests that subsidies and other material incentives are a very blunt instrument in dealing with local protest over base issues. This is because they do not deal sufficiently with the spillover effects of the bases, unlike some compensation arrangements for energy facilities or public works projects which can directly mitigate some of their impact and result in risk reduction to communities (Lesbirel 1998: 32).

Moreover, compensation politics exploits the economic weakness and subsidy dependence of Okinawa because economic stimulus and government handouts have become such a necessary prop to the prefectural economy. Not surprisingly, local government in Okinawa is exceptionally constrained 'by their dependence on the central government for budgetary transfers' (McKean 1993: 79), in contrast to many other local governments in Japan. As Smith observes: 'A powerful state can take advantage of the vulnerability of a particulardistrict' (Smith 1986: 163).

\section{Limitations of the system of representative politics}

The Okinawans have had limited political redress on the base issue through the system of representative politics in Japan. All those Japanese politicians who do not represent Okinawan constituencies and who make up the vast majority of Japanese Diet members (there are only two representatives from Okinawa out of 152 prefectural constituency representatives in the Upper House and only three representatives from Okinawa districts out of 300 in the Lower House) 'are delighted to have all the bases kept in a small southern island far from their own homes and supporters' (Johnson 1996: 2).

The fact that anti-base pressure in Okinawa is not felt directly in Tokyo through the electoral process can be seen from the votes in the Lower House on the legislation in April 1997 allowing the US military on Okinawa to continue using land beyond the 14 May expiration of leases. Some 90 per cent of the 
House voted in favour of the bill. In addition to the LDP, the right-wing New Frontier Party, the centre-left Democratic Party of Japan and the Sun Party gave their support. Only the Japan Communist Party (JCP) and the Social Democratic Party (SDP), long champions of local antibase movements with their pacifist, anti-militarist and anti-US Japan Security Treaty overtones, voted against the legislation. In the SDP's case, this thoroughly alienated its coalition partner, the LDP. Furthermore, the SDP had widespread support in Okinawa, and together with the JCP, was the primary backer of Governor Ota. In fact, the concentrated presence of the US military in Okinawa was one of the principal reasons why leftwing parties remained a widely supported political alternative amongst Okinawan voters at both the national and prefectural levels. Partly as a reaction to the strong presence of the US military, Okinawa exhibited much stronger support for anti-militarist and pacifist causes than mainland constituencies. Not only did this mean opposition to the US bases and to the US-Japan Security Treaty, it also involved antipathy towards the Japanese Self-Defence Forces (SDF) and their presence in the prefecture. Given Okinawan ethnic, cultural and political history, particularly their early conversion into a garris on outpost of Japan and their sacrifices for the mainland during the Second World War, the Okinawans saw themselves as a race apart from mainland Japanese on military issues.

The force of the democratic majority, however, works against the Okinawans on the US base issue. For most Japanese politicians, the Okinawa location is politically expedient because it means the bulk of US forces can be isolated in a remote south western corner of Japan out of sight of the vast majority of Japanese. The ruling LDP understands the risks of galvanising 'not in my back yard' (NIMBY) protests and a potential voter backlash in trying to relocate US bases to other parts of Japan. These political considerations are reinforced by the demands of the US military, for whom the patent rationale has remained Okinawa's advantageous geo-strategic positioning in relation to both the Korean Peninsula and more recently China-Taiwan. ${ }^{33}$

\section{The political roles of Japanese bureaucrats}

The actions of various elements of the Japanese bureaucracy on the Okinawa base issue since 1995 provide good examples of government officials overstepping their administrative functions and assuming political roles as

33 The strategic rationale for the US bases in Okinawa is given in Defense Agency (1997: 233) and repeated in Defense Agency (1998: 266). The strategic argument is contested, however. 
advocates of specific policy choices and as participants in the electoral arena campaigning for these policies. In one much publicised episode, the élite bureaucrat in charge of the Defence Facilities Administration Agency, Hoshuyama Noboru, had to resign in October 1995 after calling Prime Minister Murayama 'dumb' for his handling of the Okinawa base issue. ${ }^{34}$ The comment stemmed from a difference in approach to dealing with Ota's refusal to sign base leases. Hoshuyama pressed for Maruyama to exercise his authority as prime minister to renew the leases in lieu of the Okinawan governor. ${ }^{35}$ Prime Minister Maruyama, on the other hand, was much more inclined to negotiate with Ota in order to persuade him to sign the renewals in place of landowners who refused (Nikkei Weekly 23 October 1995). Hoshuyama's resignation was largely due to his unfortunate choice of terminology, but the larger issue at stake was his advocacy of a policy stance that was independent of the political executive and his attempt to assert bureaucratic predominance on a matter of state policy.

Such bureaucratic attributes were even more clearly in evidence with the Foreign Ministry and Defence Agency's successful prevention of a review of the US-Japan Status of Forces Agreement (SOFA) ${ }^{36}$ in late 1995. This was explicitly called for by protesters and by Governor Ota in the wake of the rape incident. Murayama also said he was open to a fundamental review of the SOFA, but this conflicted with the avowed position of the Defence Agency and Foreign Ministry which was to avoid such a review at all costs. In the end, the latter view prevailed. A senior Foreign Ministry official asserted that the government 'had no intention of conducting a full-scale review of the status agreement'. He remarked: 'The agreement and the Japan-U.S. security treaty are two sides of the same coin', adding that: 'Reviewing the framework of the status agreement would have a large impact on Japan's national-security policy. Another official questioned: 'How do you think the agreement can be reviewed?...Cooperation of the US government would definitely be needed' (Nikkei Weekly 23 October 1995).

34 The comment reportedly was made during Hoshuyama's briefing to reporters. The word baka was probably used. It translates as 'stupid', 'dumb' or 'muddleheaded'.

35 He said Prime Minister Murayama should sign documents to force unwilling landowners in Okinawa to renew contracts to rent their land to US forces (Australian 20 October 1995).

36 A Joint Committee set up under this 1960 agreement determines the specific facilities and areas to be used by USFJ and outlines the conditions under which US military personnel are deployed in Japan. It effectively legitimates the presence and activities of US troops in Japan, including the use of Japanese-owned land by the US military, military training on Japanese territory and special legal status for US military personnel (Nikkei Weekly 23 October 1995). 
The strongly held positions of the Foreign Ministry and Defence Agency on the SOFA issue and the fact that no review of SOFA took place underline the widely accepted view that it is not the Japanese prime minister but the Foreign Ministry and Defence Agency who are the primary guardians of the US-Japan alliance and Japan's security interests more generally. This is despite the fact that the Constitution (Article 72) bestows clear supremacy (constitutional jurisdiction) on the prime minister in the area of foreign relations and foreign policy, ${ }^{37}$ and the 1954 Self-Defence Forces Law allots him the position of commander-in-chief of the armed forces.

Evidence of government officials usurping the roles of politicians also surfaced in relation to the Futenma relocation issue. In a clear breach of legal provisions prohibiting the involvement of public officials in election activities, Defence Agency officials were dispatched prior to the Nago plebiscite in December 1997 to try and influence local voters in favour of the sea-based facility. They visited voters' homes and urged them to support the heliport plan (Miyagi 1998: 2). ${ }^{38}$ Moreover, despite protests from various democratic groups, the plebiscite was not made subject to Japanese election laws (Miyagi 1998: 2), which prohibit electioneering activities such as vote-buying and door-to-door canvassing. One Defence Agency official even ventured the observation that referenda like the one opposing the construction of a heliport off Nago town in Okinawa were 'destroying Japanese democracy' because 'under such a system a majority can force its opinion on the minority’ (Asahi Shinbun 18 July 1998).

Governor Inamine was subsequently challenged by government officials with respect to his proposal that the Futenma relocation issue could be solved by his plan for a joint civilian-military airport in northern Okinawa with a fifteenyear lifetime. The most senior bureaucrat in the Defence Agency, Akiyama Masahiro, commented: 'It is difficult to set a fixed term for the use of such a facility' (Nikkei Weekly 23 November 1998). A Foreign Ministry official also expressed doubts about the practicality of Inamine's idea of building an alternative base for US marines and civil airlines (Asahi News 16 November 1998).

37 It states: 'The Prime Minister, representing the Cabinet, submits bills, reports on general national affairs and foreign relations to the National Assembly and exercises control and supervision over various administrative branches.'

38 Elsewhere Johnson reports that the LDP 'sent in officials of the Defense Agency and other ministries to try to buy votes with promises of subsidies' (Johnson 1998: 1). 


\section{Government responsiveness to anti-base protests}

One measure of the quality of democracy in any country is the government's predisposition to respond to popular protest movements and its treatment of minorities. On a nation-wide scale, anti-base elements in Okinawa quite clearly represent a minority interest. Within Okinawa itself the issue is a little more complicated. The assumption in a lot of the commentary on US bases in Okinawa is that most of the prefectural inhabitants want the US bases removed. The reality is, however, that the Okinawans are quite sharply divided on what to do about the bases. In the September 1996 referendum on the US bases in Okinawa, only 53 per cent of total eligible voters agreed with the proposition that the SOFA should be reviewed and American bases reduced, although 89 per cent of those who actually cast their votes supported the proposition (Eldridge 1997: 879). ${ }^{39}$ The second, non-legally binding referendum was held on the Nago heliport issue in December 1997, in which a small majority of Nago residents voted against the construction of the offshore floating heliport (53.83 per cent) whilst supporters numbered 46.1 per cent.

Majorities that have gone the other way have been equally close. In the February 1998 mayoral election in Nago, Kishimoto Tateo who was sympathetic to the heliport plan won with 16253 votes against Tamaki Yoshikazu, who was backed by Ota and opposed the heliport with 15103 votes (Nikkei Weekly 16 February 1998). Likewise, in the November 1998 election for the governorship, Inamine won 52.1 per cent of the vote (374 833 votes) compared to Ota's share of 46.9 per cent (337 369 votes) (JPRI Staff 1998: 1).

Okinawan opinion on the US bases is divided principally along lines of economic interest, with the main arguments for and against the bases centring on the material benefits generated by the bases and by the government's compensation policies, versus the social and environmental costs exacted by the bases themselves. In particular, it is Okinawa's economic weakness that excites some residents' concerns about the prospect of base removal and makes them vulnerable to inducements offered by the central government and by Governor Inamine. While Okinawa may no longer be a base-dependent economy, 'worries about lost income once the bases depart make landowners and others in the business community a small but influential constituency that favors the American presence out of necessity' (Smith 1998: 2).

39 As he points out, although 89 per cent of those who voted agreed with the proposition, only 59.53 per cent of eligible voters cast their vote at the referendum. 
Amongst base leasees, for example, the majority of landowners who gain lucrative income from their base leases are in favour of continuing the arrangement. ${ }^{40}$ Only 3000 out of 32000 landowners refused to sign the extension of their base leases in 1996-97.41 The majority of Okinawa property owners opposed the plan put up by the prefectural government in early 1996 for removal of all bases by 2015. An association representing 20000 landholders said 'the blueprint lacks clear redevelopment ideas and closures of the bases would deprive them of rental income' (Nikkei Weekly 5 February 1996).

Other groups supporting the US military presence in Okinawa are construction contractors whose lifeblood are the public works contracts financed by central government subsidies, small business owners such as shopkeepers, bar operators, and other small businesses that rely on the patronage of service personnel from the bases (Eldridge 1997: 897), and the relatively modest numbers of base workers. ${ }^{42}$ Eldridge calculated that in the town of Kin, Camp Hansen (a marine base) and other US military facilities 'occupy close to $60 \%$ of the land', with approximately $\$ 2.5$ million in revenue generated annually due to its presence in the form of rental income from base leases, spending by military personnel and 'host town compensation support'

40 Eldridge reports that $¥ 70.4$ billion ( $\$ 641$ million) is paid annually for the land leased in Okinawa, the average landowners receiving rental income of around $¥ 2$ million (\$18 2000), 'slightly less than the prefecture's average annual per capita income' (1997: 896). In short, this is a major source of income for many landowners, and the end to base leases would terminate this valuable source of income. The organisation of landowners with around 28000 members is the Okinawa Federation of landowners of Land Used for Military Purposes, and it organises 26 landowner associations from 27 cities, towns, and villages (ibid). Landowners had to be compensated with amounts equivalent to three years of rent for the transferral of land back to them from the US military as a result of the SACO proposals. The prefectural government later proposed that this should be increased to seven years in the case of the Futenma landowners (Okinawa Weekly Times 30 October 1999).

41 One report said that of the approximately 32000 private land leases being used for US military bases in Okinawa, 29000 owners had agreed to continue lease agreements with the central government, but the remaining 3000 were refusing to renew their leases. A total of 2900 of these were politically motivated owners who each held one tsubo (one tsubo is the smallest unit of land measure in Japan, equally two Japanese tatami mats or about or 3.3 square metres/40 square feet), and who belonged to the anti-base 'One Tsubo Movement'. Of such owners, 1400 lived outside Okinawa Prefecture (Nikkei Weekly Editorial, 16 September 1996). The One Tsubo Movement had the slogan: 'Change the military bases into places for life and productivity'. They were ridiculed by the Director-General of the Japanese Defence Agency as 'cushion landlords' and 'handkerchief landlords' because of the small size of their leased plots.

42 Eldridge puts these at 8300 (1997: 895); compare with footnote 26 above. 
from the national government, a sum that 'represents close to $50 \%$ of the town's total revenue' (1997: 897-8).

To some extent, Okinawa is also ideologically fractured on the base issue. The political left and centre-left led by members of the SDP, JCP and the prefectural branch of the Japanese Trade Union Confederation (Rengo) are dominant amongst opponents of the US bases, while LDP supporters including the SDF in Okinawa (who also have bases there), who are ideologically opposed to anti-base movements and who support the need for the US military presence, are prominent amongst base supporters.

In Okinawa, as in many other prefectures, left-wing parties have often been much more politically successful at the local government level than at the national level. This has enabled their bcal-politician members to use protest issues like antibase movements to fight a broader ideological battle with their conservative opponents in the national government, particularly on issues like security and defence. The JSP mayor of Yokohama, for example, used the local road regulations to halt temporarily the movement of US military vehicles during the Vietnam War.

The overall picture is not, therefore, clear-cut. While a sizeable majority of Japanese want US bases to be kept in Okinawa (if Japan is to have any US bases at all) and a small majority of Okinawan citizens want the US bases removed, or at least severely reduced, the vehemence of the anti-base protests in Okinawa since 1995 and the defiance of Governor Ota in the face of central government authority has given the Japanese government pause to reflect on the shortcomings of its previous management of the domestic angle on US bases in Okinawa. Consequently, the government's actions over the past four years provide an opportunity to reassess its record. What, for example, does the central government's performance indicate in terms of its responsiveness to the demands of regionally-based minority groups? How effective were the anti-base protests? What did they want and what did they get?

On balance, the outcomes were mixed. On the one hand, the Japanese government failed to capitulate to the demands embodied in the September 1996 Okinawan prefectural referendum when 89 per cent of those who cast their vote called for a reduction in the US bases and for a review of the SOFA. On the other hand, after the outcry over the rape of the Okinawan schoolgirl and the calls for a reduction in the US force presence, Prime Minister Murayama was expected to ask President Clinton during their scheduled November 1995 summit in Tokyo to reduce the US military presence in Okinawa. According to the Chief Cabinet Secretary, Nosaka Koken, the prime minister would 'have to' make such a proposal because of the outcry over the rape (Australian 20 October 1995). On the 
day the guilty verdict was announced for the three American servicemen for rape, the Japanese and US governments agreed to limit flying hours for US military aircraft at Kadena Air Base and Futenma Air Station in Okinawa. They were made the same as those in effect at Atsugi Naval Air Facility in Kanagawa Prefecture and Yokota Air Base in Tokyo, which prohibited US aircraft from flying between 10pm and 6am, except for emergency operations (Nikkei Weekly 11 March 1996).

Moreover, in order to contain and deflect popular protests on Okinawa and prevent them from developing into a domestic crisis of base management or, even worse, a foreign relations crisis of alliance management, the Japanese and American governments moved swiftly to set up a joint committee, the Special Action Committee on Okinawa, or SACO (Okinawa ni kansuru Tokubetsu Kodo Iinkai) only two months after the rape and one month after some 85000 Okinawans participated in a massive demonstration against the US bases, ${ }^{43}$ the biggest protest against US bases in the prefecture's history since the 1950s.

SACO was established to make recommendations about repositioning, reducing and realigning US bases on Okinawa, with a view to mitigating the burden of the US military presence on the island and tackling 'such thorny points as aircraft noise' (Nikkei Weekly 5 February 1996). On the other hand, the opportunity to bring Okinawans into the official bilateral consultation process was passed over. SACO was composed of US and Japanese government officials (on the Japanese side, senior officials at the Foreign Ministry and Defence Agency) without any representation from Okinawa. What the Okinawan prefectural government wanted was submitted to the central government outside the formal SACO process. Delegates led by Vice-Governor Yoshimoto Masanori offered a plan to the central government in early 1996. The plan requested the return of all lands being used for US military facilities by 2015. It suggested the return of ten facilities, including Futenma Air Station by 2001; another fourteen facilities by 2010 and the remaining seventeen, including Kadena Air Base, by 2015 (ibid). This demand has only been partially met.

The December 1996 final report of SACO made 27 recommendations proposing: return of land (some 21 per cent of Okinawan land amounting to 5002 hectares occupied by the US military over 57 years as a result of base realignment and consolidation), ${ }^{44}$ although no military functions of the USFJ

43 Organisers of the protest estimated that demonstrators numbered 85000 although the police estimated 60000 .

44 The report named eleven facilities to be returned including Futenma, and gave deadlines for ten of them. In almost all cases of base return, a prerequisite was the transfer of base functions to other bases or facilities in Okinawa or, in a few cases, relocating the 
would be compromised and the total level of US military personnel on the island would remain unchanged at 28000 ; adjustments in training and operational procedures, including the cessation of live artillery fire over route 104, a main thoroughfare in Okinawa (by the end of March 1998) and curtailing 'to the maximum extent possible' night flight-training operations at MCAS Futenma; and various noise abatement procedures (Nikkei Weekly 9 December 1996; for details, see Defense Agency 1998: 420-6). Most of the facilities and operations on land to be returned to Okinawa would be transferred to other military facilities in Okinawa, not to other prefectures (Nikkei Weekly 9 December 1996). The extent of the changes was praised by US Ambassador to Japan, Walter Mondale, who said: 'More work has been done in the last year than in the preceding 25 years put together' (ibid).

On the other hand, many Okinawans were infuriated when they realised that the US military would be relocating but not declining. The concessions were only partial, plus there was to be no revision to the SOFA (Australian 2 November 1995). Although Ota and his supporters had wanted a reduction, what they got was a 'readjustment' described by some as a 'cosmetic 'burden reduction' (Takazao 1998: 1). According to Kuwae Teruko, chief secretary of a women's group lobbying against US military bases and troops on Okinawa: 'The return of the land by itself does little to solve the problems...We want to see a reduction of the functions of the bases, not the size of the land' (Nikkei Weekly 6 May 1996).

Furthermore, a precondition for returning Futenma Air Station in from five to seven years which was agreed by the Japanese and US governments, was building replacement facilities within Okinawa itself. By July 1996, the national government was unable to find an alternative site for Futenma, with local residents in places under consideration voicing opposition. SACO thus became bogged down with the difficult task of finding an alternative site for Futenma Air Station. The final SACO Report stated 'that construction of a sea-based facility (SBF) on the sea off the eastern coast of Okinawa main island should be

functions of some military training areas in Okinawa to several sites outside the prefecture, and in the case of Futenma Air Station, creating another facility in Okinawa altogether. Including Futenma, the American bases affected were the Northern Training Area (a major portion of which would be returned by the end of March 2003), Aha Training Area, Gimbaru Training Area (the last two to be returned by the end of March 1998), Sobe Communication Site, Yomitan Auxiliary Airfield (the last two to be returned by the end of March 2001), Camp Kuwae, Senaha Communication Station, Makiminato Service Area, Naha Port, and housing consolidation at Camp Kuwae and Camp Zukeran (Defense Agency 1998: 421-2). The plan was praised by Ota because 'it calls for the return of most of the facilities the prefecture hoped the U.S. would return by 2002' (quoted in Nikkei Weekly 9 December 1996). 
pursued, since the project was judged to be the best option' (Defense Agency 1997: 234).

As already noted, however, the idea of building a heliport off Camp Schwab in Nago sparked strong opposition especially from the residents of Nago, the proposed hometown of the heliport. The Mainichi accused the central government of attempting 'to force its heliport plan down Okinawa Prefecture's throat' (Mainichi Editorial, 1 September 1998). On the other hand, former Prime Minister Hashimoto was quoted as saying that: 'The heliport will not be built without local consent' (BBC Monitoring Service: Asia-Pacific 6 August 1998). ${ }^{45}$

The government announced the cancellation of the heliport plan in the midst of the November 1998 Ota-Inamine election campaign, thus taking the wind out of the sales of the pro-Ota forces. The decision ended two years of stalemate over the proposal. Inamine's view was that the proposal could not be implemented because in the Nago plebiscite, the majority had voted against it. Instead, he proposed that the air base could be relocated to northern Okinawa on a joint military-civilian use basis with a fifteen-year life span.

Altogether it took the central government and the Okinawan prefectural government three years from the final SACO report to reach a final resolution of the Futenma Air Station relocation issue. It was a long drawn-out process of political compromise, in which the central government learned that it could no longer impose solutions on the people of Okinawa. The floating heliport idea was rejected by the Japanese government ultimately because both Ota and Inamine were against it and the LDP could find no ally in an Okinawan governor to act as its local promoter. The concept became politically impracticable given this fact, and thus the people of Okinawa won a victory of sorts over the issue. The Mainichi reported that

...after the plan was voted down in a referendum held in Nago, the central government abandoned its top-down approach and decided to delegate responsibility for choosing the site to the people of Okinawa. This is a positive development. Whenever the government attempts to hurry the process along without obtaining the consent of the people of Okinawa, it is bound to repeat the mistakes of the past (Mainichi Daily News 7 September 1999).

45 Similar sentiments were expressed by the newly appointed Japanese ambassador to the United States, Yanai Shunji, who commented that: 'If the military facilities in question are to be relocated within the prefecture, no decision should be made without obtaining the consent of local communities and incorporating the opinions of local authorities at various levels, including the prefectural government' (Daily Yomiuri Online 13 September 1999). 
The final outcome, however, was only a qualified victory. Okinawa lost on the larger question of relocating the base within the prefecture itself. In late 1999, Governor Inamine decided that the new air station would be built in the Henoko district of Nago, a proposal that was officially accepted by Mayor Kishimoto and the municipal assembly. Following Kishimoto's decision to approve the relocation plan, it was officially endorsed by the Japanese Cabinet in late December 1999.

Characteristically, compensation was the sweetener in the deal. As an inducement to acceptance, the central government announced new policies to promote the economy of the local region including he establishment of a foundation for the development of northern Okinawa, the passage of a law aimed at economic development, and the appropriation of $¥ 100$ billion over ten years to promote the regional economy of northern Okinawa Yomiuri Shinbun 27 December 1999). The proposals were drafted on the assumption that the heliport functions of MCAS Futenma would be relocated to Nago (Yomiuri Shinbun 15 December 1999), thus making compensation contingent on base acceptance.

Despite the apparent settlement of the Futenma relocation issue, it still retains the potential to inspire the protests of local residents as well as of anti base groups within Okinawa as a whole. Many locals are against the idea of relocating the air station to a land-based facility in Henoko, and would have preferred the floating air base. ${ }^{46}$ Moreover, there are as yet unresolved issues relating to some of the conditions imposed on the relocation by both Governor Inamine and Mayor Kishimoto. It remains to be seen, for example, whether the US military will be prepared to accept the fifteen-year time limit on the use of the new facilities. The G8 summit in July 2000 is also vulnerable to disruption from anti-base campaigners.

The mixed outcomes on the Okinawa base issues suggest that the Japanes e government is moderately responsive to protest action, even that which impacts directly on a key pillar of its security policy. Over the past four years, the government has learned a great deal about what it can and cannot do with respect to the US bases on Okinawa. Moreover, it has gone some way towards adjusting arrangements for base functioning in the face of local resentment. This is no mean achievement given the non-negotiable alliance premises on which it

46 Even the final decision on this has been delayed because of government fears of protests during the G-8 summit in Nago next July (Daily Yomiuri Online 25 November 1999). In a December 1999 poll of Okinawans conducted by the Asahi Shinbun and Okinawa Times, 45 per cent of respondents opposed the relocation of Futenma to Nago, compared with 32 per cent who supported the plan Asahi News 7 December 1999). 
operates and the inevitable NIMBY phenomenon on the mainland which restricts potential relocation options.

Prime Minister Murayama in late 1995, for example, sought ways to relocate part of the US military, but his approach was called unrealistic on the grounds that residents of the newly chosen sites would heatedly protest (Nikkei Weekly 23 October 1995). The Hokkaido branch of Murayama's own SDP submitted in October 1995 a formal request to the governor of Hokkaido that Japan's northernmost main island not build a shooting range for US troops that could replace a similar one in Okinawa. Earlier, a town in Hokkaido passed a resolution vowing not to accept any US military facilities, and others considered taking similar steps (Nikkei Weekly 6 November 1995).

The NIMBY phenomenon was strongly in evidence with respect to the various proposals for relocating bases and their functions to other parts of Okinawa and mainland Japan as part of the SACO Agreement. In almost all cases of base return, a prerequisite was the transfer of the bases or base functions to other areas or facilities in Okinawa and in a few cases to other bases in the rest of Japan. This was strongly opposed by the municipalities and residents affected by it.

For example, when the plans were announced for shifting some of Futenma's functions to other bases in Japan and Okinawa, they drew an angry response from cities that would take over the role of the facilities due to be closed. The mayor of Iwakuni City in Yamaguchi was outraged when he heard that twelve Hercules aircraft based at Futenma Air Station were to be relocated to Iwakuni Air Base. 'We have been completely betrayed and I am absolutely outraged', he said (Australian 15 April 1996). He protested the move to Defence Facilities Administration Agency Director-General in Tokyo, and he also met with Hashimoto to express his anger (Nikkei Weekly 6 May 1996).

In August 1996, SACO agreed to move live-fire exercises outside Okinawa to the mainland. The national government agreed to find five other sites in Japan for artillery drills that took place across a heavily used highway in Okinawa. But most of the prefectures proposed as new sites voiced their opposition to the plan (Nikkei Weekly 2 September 1996). The governor of Yamanashi Prefecture refused a request from the Defence Agency to provide land for one of five alternative sites. Leaders in the other four prefectures also opposed the plan (Australian 20 August 1996). 
The NIMBY phenomenon means that for the US forces to leave Okinawa in any strength, they effectively have to leave Japan. ${ }^{47}$ Although the functions of some military training areas in Okinawa were successfully relocated to several sites outside the prefecture (BBC Monitoring Service: Asia-Pacific 3 August 1998), few Japanese mainland politicians are willing to accept a redistribution of the burden to their constituencies.

\section{Strengthening participatory democracy}

Popular protests against the US bases in Okinawa, the resort to citizen-initiated referenda under the auspices of local government to determine public sentiments regarding base-related issues, ${ }^{48}$ the challenge thrown down to central government power by the defiance of Governor Ota in refusing to cooperate with procedures required for the renewal of base leases, and the case Ota argued before the Supreme Court in asserting the rights of local communities to 'home rule' are very much in the tradition of citizens' movements in Japan, which have been integral to the development of indigenous ideas of decentralisation and the development of local autonomy (McKean 1981: 252). Anti-base activism in Okinawa in which local government leadership has played such a critical role is symptomatic of the increasingly vocal demands 'of prefectural and municipal governments in Japan for greater local autonomy, the questioning of central power by local voices, and of the citizens of these local communities for more direct democracy' (see Arase 1998: 6).

The Okinawa base problem has actually served to strengthen participatory democracy in Japan, with copycat strategies being employed by other local protest movements. An increasingly popular weapon in the hands of local activists protesting developments with NIMBY-type implications is the use of non-binding referenda. As Johnson observes:

The local plebiscite, almost never used in Japan until the late 1990s, has become by far the most important institution in the country through which ordinary citizens can democratically express their will (1998: 2).

47 Yamasaki Taku, senior member of the LDP and former Director-General of the Defence Agency, said 'that relocating U.S. bases in Okinawa to elsewhere in Japan would only create similar problems at the new sites'. Because of this, the 'Japanese government needs to take concrete measures to reduce the burden on Okinawa, and should request U.S. cooperation "to move some forces out of Japan"” (Nikkei Weekly 6 November 1995).

48 What was unprecedented about what took place in September 1996 in Okinawa, however, was that it was the first prefectural-level referendum ever to be held in Japan (Eldridge 1997: 880). 
Although it is argued that Japanese citizens have the right to initiate public referenda according to Chapter 8, Article 95 of the Constitution pertaining to Local Self-Government (Eldridge 1997: 880), ${ }^{49}$ providing due procedures laid down in the Local Autonomy Law are followed, ${ }^{50}$ the constitutional status of plebiscites is not established in Japan, and because of that ballot results are not legally binding (Nikkei Weekly 19 August 1996).

Politically, however, it is a different story. Exercises in direct participatory democracy such as the plebiscites held in Okinawa represent expressions of popular will that are difficult for the central government to ignore, even if their results are non-binding. Although the LDP has opposed the holding of these referenda and has actively campaigned against them, ${ }^{51}$ or tried to configure plebiscite questions to bring about the desired result (for example, Nago), ${ }^{52}$ it has not been able totally to reject expressions of popular will embodied in antibase referenda.

In August 1996, with the battle over Okinawa bases at its height and with the impending Supreme Court decision on Ota's appeal and the Okinawa base referendum pending, the citizens of Maki, a town in Niigata Prefecture, voted against the construction of a nuclear power plant which had been in the planning stage for over 25 years. Similar plebiscites were held in other local communities such as in Mie, Nagano and Kochi Prefectures relating to the construction of unwanted facilities (Eldridge 1997: 880). ${ }^{53}$ At present, thirteen

49 This is a contested view. The constitutional article states that 'a special law, applicable only to one local public entity, cannot be enacted by the Diet without the consent of the majority of the voters of the local public entity concerned, obtained in accordance with law'.

50 The relevant clause in the law is Article 74 which requires that the signatures of 1/50th of the eligible voters are needed to request a referendum (Eldridge 1997: 885).

51 For example, the LDP organisation in Okinawa called for a boycott of the September 1996 referendum (see Eldridge 1997).

52 Johnson reports that the LDP 'tried to sabotage the vote by offering the voters four choices instead of the usual two' (1998: 2).

53 Eldridge maintains that these plebiscites were binding. In the case of Maki, however, Tohoku Electric Power Company has not given up the idea of locating a nuclear power plant in the two, and announced that it will begin construction in 2002 (Asahi News 21 April 1999). A more recent development should also be noted in Yamaguchi where Chugoku Electric Power Co., which plans to build a nuclear power plant in the prefecture, has offered eight local fishery cooperatives $¥ 6$ billion in compensation for potential damage to fisheries in the Seto Inland Sea. The company will probably outlay $¥ 10$ billion altogether, as it is also expected to propose a fisheries-development package to the cooperatives. Only one of the cooperatives is still reportedly opposed to the nuclear power plant, the first to be built on the shores of the inland sea. Another 
new nuclear power plants are planned throughout the country, but most of them are meeting stiff opposition from local residents, and ordinances for plebiscites have been passed in two more towns affected. Although it is private energy companies involved in the negotiation and compensation process, behind them stands the Japanese government with its strong commitment to nuclear energy as a source of electricity supply. Citizens' movements in other regions also want to follow the Maki example by holding referenda on the construction of largescale projects, in this instance public works projects financed by the Japanese government. ${ }^{54}$ Plebiscites are becoming a standard weapon in the arsenal of local government politicians who seek to reflect citizens' views on central government development proposals.

Moreover, political exercises in the form of plebiscites are gaining ground at the expense of compensation strategies which are ceasing to work as effectively as in the past. As one Japanese journalist commented: 'Towns and villages are rich enough now. They have good roads, bridges, harbors, schools, town halls and the like. Additional economic incentives are no longer as attractive or effective as they used to be' (Nikkei Weekly 19 August 1996).

They still work in a place like Okinawa because of its economic weakness, although a similar comment has also been made about Okinawa:

In the past, fiscal assistance worked to quell complaints of the Okinawans about inconveniences caused by the presence of U.S. bases and troops...But because the commercial value of the lands used for U.S. bases is now increasing, many people want their lands back instead of just getting cash (Miyazato Seigen, Professor of International Relations at Dokkyo University, quoted in the Nikkei Weekly 22 July 1996).

The calculus of economic incentives contained in compensation packages may increasingly become redundant which will throw issues back into the political realm. In fact, citizens' movements actively work to reduce the appeal of local development incentives by appealing to alternative values such as preservation of the environment, quality of life, reduction in the risks associated with noxious facilities; in other words, protection of interests that regional communities themselves regard as important,${ }^{55}$ together with greater local

plant - this one in Aomori Prefecture - was given the go ahead in August 1998, the first in ten years (Yomiuri Shinbun 27 December 1999).

54 The best examples are the Kobe municipal airport against which 308000 voters signed a petition for a referendum, and the Yoshino dam in Tokushima Prefecture where citizens' groups are also seeking a referendum.

55 For example, a local farmer and fisherman in Tsugen-jima, a possible alternative site for Futenma Air Station, commented: 'I can't fault anyone for wanting an easier life 
participation in decision making, and greater accountability and responsiveness in national government (McKean 1981: 253). ${ }^{56}$

On the same day as the Maki referendum, the Japanese government ran a full-page advertisement in 75 newspapers throughout Japan seeking to promote the importance of the security treaty with the United States, of maintaining US military bases in Okinawa and of relocating some of the facilities to other parts of the nation (the government's position) (Nikkei Weekly 19 August 1996). This was an unprecedented move but it was the central government's response to a phenomenon that both the anti-base movement in Okinawa and the Maki antinuclear movement had in common: 'conflict between the central government's policy and the interests of localities over issues with nationwide implications' (ibid).

It is quite possible for local communities to reject facilities and development proposals for their area even though they accept the larger policy at stake such as the US-Japan security treaty and the government's nuclear energy policy. In short, residents' movements are often NIMBY protests pure and simple. Nevertheless, the battle is being played out between local communities and the central authorities, with regional areas who bear the concentrated costs of largescale development projects such as dams and airports, and the siting of noxious facilities (including bases), refusing to allow their interests to be arbitrarily overridden in the name of national policy which is justified by the diffuse gains it generates for the Japanese community as a whole.

How to resolve political conflicts where local communities bear the brunt of national policies is becoming increasingly problematic for the Japanese government. The political agitation of local communities is posing an everstronger challenge to Japan's highly centralised administrative system which is viewed more and more as 'suppressing and marginalising local interests and selfgovernment' (Nikkei Weekly 19 August 1996). A writer in the Nikkei Weekly observed that: 'The tendency undeniably has been to impose decisions made at the center upon localities. These tendencies, which have added to the distrust of the central government and the nuclear industry, must be corrected quickly' (ibid).

with more money to spend...But we already have all we really need. I have no desire to sacrifice my quiet, peaceful life for extra money' (Asahi Shinbun 4 May 1999).

56 It is interesting to note that Governor Inamine, after the resolution of the Futenma issue, requested not only subsidies for economic promotion in the northern part of the prefecture, including Nago, but also the 'setting up of an organisation where the central and prefectural governments, as well as local cities, towns and villages, can discuss the matter' (Asahi Evening News 19 November 1999). 
Open challenges to centralised authority by local communities and local governments are putting Japan's democracy to a severe test.

Other instruments of the popular will are the unanimous resolutions of local assemblies as an expression of the will of the local electors. In July 1996, the Okinawan prefectural assembly unanimously adopted a resolution calling for the return of Futenma Air Station land and opposing relocation of US military facilities in Okinawa Nikkei Weekly 22 July 1996). ${ }^{57}$ A number of unanimous resolutions of Nago City Council against the heliport plan also occurred as part of the antiheliport campaign.

On the other hand, some resolutions are passed in a greater spirit of compromise. In November 1999, the Ginowan municipal assembly passed a resolution (by a margin of only one vote) favouring the relocation of MCAS Futenma to another site in Okinawa, rather than outside the prefecture altogether. This assisted the final stages of resolving the issue, as did a supportive municipal assembly resolution in Nago itself in late December.

Despite these demonstrations of people power, they are not always accepted as proper demonstrations of representative democracy. The LDP in Okinawa Prefecture opposed the 1996 Okinawa referendum on US base reductions on the grounds that a 'direct vote through a referendum "[went] against parliamentary democracy”.' (Ryukyu Shinpo, quoted in Eldridge 1997: 888). The chairman of the LDP prefectural federation in Okinawa argued that 'the plebiscite...would "lead to a denial of parliamentary democracy by bypassing already elected representatives"...[and that it] disregarded "the proper procedures of parliamentary democracy, i.e., entrusting elected representatives to defend the interests of the group".' (Eldridge 1997: 894). After the referendum was held it was denounced as 'not democracy b ut mob rule' (Eldridge 1997: 895). Critics, however, maintained that the local LDP's anti-referendum stance and the chairman's urging were 'interfering with individual citizens' rights and responsibilities' (Eldridge 1997: 900).

Referenda are certainly not part of Japan's defence policy-making structure, but because they can be organised at the local level against bases, they can have an effect on security policy. As Eldridge observes,

57 Similarly, the assembly of Mizuho, a town which Yokota Air Base straddles outside of Tokyo, adopted a resolution in May 1999 that supported Ishihara's call for the return of the base (Asahi Evening News 27 May 1999). 
...the nonbinding prefectural referendum was a direct challenge to the entral government's authority in a policy area that is politically and constitutionally recognized as being within its administrative jurisdiction, namely, national defense and bilateral treaty obligations (Eldridge 1997: 881).

The protests and direct action in Okinawa have emboldened other Japanese citizens to act against US bases. The outcry over the Okinawa rape sparked grievances against the US military, with thirteen municipalities surrounding the US-Yokota Air Base in Tokyo passing resolutions calling for a ban on night-time flights Weekend Australian 30 September-1 October 1995). Moreover, local assemblies in several Japanese cities that host US military bases adopted resolutions calling for a review of the SOFA in the wake of the 1995 rape of the Japanese schoolgirl.

These kinds of protest actions have begun to affect other aspects of the US-Japan security relationship. In the wake of the passage of the US-Japan Defence Cooperative Guidelines in May 1999, a newspaper survey revealed that 177 governments in 32 prefectures had adopted resolutions against the guidelines by April 1999 (Asahi News 29 April 1999). In May 1999, a network of prefectural and municipal assembly members and residents against nuclear weapons issued a declaration of 'non-submittal' to the bills, calling on local governments, organisations and businesses to resist requests from the central government to cooperate with US forces (Asahi News 25 May 1999).

\section{Conclusion}

The 'Okinawa problem' has overshadowed Japanese security policy ever since the rape of a Japanese schoolgirl by three US servicemen in September 1995. The continuing imbroglio over relocating MCAS at Futenma has also kept the base issue alive in spite of all attempts of the central government to neutralise it.

In addition to assertions of superior executive, statutory and legislative authority, political and bureaucratic élites in Tokyo have deployed a twopronged strategy for dealing with the Okinawa base problem: economic blandishments combined with limited reshuffling of base locations and base functions, plus some amelioration of the noxious spin-offs from bases for the Okinawan people. However, the government's room to manoeuvre in terms of actually reducing the US force presence in Okinawa has been extremely circumscribed because of possible domestic political repercussions on the mainland and American demands to avoid any loss of military function, and because Japan's base commitment is the chief contribution it makes to the alliance, given its inability to contribute in other ways, such as collective self- 
defence. Indeed, the new defence cooperation guidelines that take Japan about as far as it can go short of participation in collective defence (see George Mulgan 1999) can be interpreted partly as compensation for the concessions that the US military has had to make with respect to the Okinawa bases. An overriding priority for the Japanese government has been to avoid endangering the US-Japan Security Treaty and the US commitment to the defence of Japan. This helps to explain why it has consistently viewed the base issue as a foreign policy issue rather than as a domestic issue and thus why it has been so unresponsive to local antibase protests in the past. Both the Japanese and American governments continue to rate the views of Okinawans as subordinate in relation to the larger question of the geographic distribution of US bases in Japan. Other considerations have a higher priority and limit their willingness to accommodate the complaints of the Okinawans on base issues. The combination of Japanese policy priorities and American geo-strategic calculations means that removal of the US bases from Okinawa is primarily contingent on American strategic withdrawal from East Asia, not on localised political opposition in Okinawa.

Nevertheless, both governments now accept that they must respond constructively to popular protests arising from the US force presence in Japan, that base-related issues can no longer be ignored or shunted aside, and that these issues must be recognised and factored into the US-Japan security relationship. In a reversal of the customary uni-directional impact of Japan's strategic policies on local communities, what has happened in Okinawa since 1995 has sensitised the Japanese government to local community reactions to the bases in their midst. Despite the makeup of SACO, the principle of popular consultation has been entrenched, with the Futenma relocation question being a good example. Greater efforts have been made to gain the 'understanding' of the local communities involved ${ }^{58}$ and, where there are significant levels of opposition, the government has shown a greater preparedness to back down. It can no longer do what it did prior to or during World War II-arbitrarily expropriate land for military use-or 'override the local will' as Governor Ota argued it did in his testimony before the Japanese Supreme Court in July 1996 ('The Text of Governor Ota's Testimony', in JPRI 1997: 3). Nevertheless, the forcible acquisition of land - the fait accompli by the Americans in the 1950scontinues with the assent of the Japanese government. The bottom line also

58 See, for example, the text of the Japan-U.S. Joint Declaration on Security-Alliance for the 21st Century, 17 April 1996. 
remains the same. Most US bases remain in Okinawa and ultimate jurisdiction on base issues lies with the central government.

To some extent, however, the anti-US base movement in Okinawa has corrected the over-centralisation of national government power on this issue, at least in terms of practical politics. While local governments may not be in a position to decide matters affecting bases, they and their supporters can mobilise against them in public campaigns. This has provided a model for other locally-based NIMBY movements to emulate, pushing the boundaries of citizen participation in Japan as well as local government challenges to central authority.

The way in which the Japanese government has responded to the local protests in Okinawa against the US bases reveals much about Japan as a functioning democracy. It illustrates the level of state responsiveness to direct action by local political leaders and communities, the role of the Supreme Court as a defender of establishment policies, the inherent tension between centralising and decentralising state power, the assumption by central government bureaucrats of political as well as administrative roles, and the quick resort to and over-reliance of political and administrative élites on compensation strategies in policy bargaining contexts. On balance, while the anti-base elements in Okinawa won only a qualified victory, to some extent they engendered a greater consciousness of the Okinawa base issue in government institutions and thus a greater responsiveness to demands for redress.

\section{References}

Arase, David (1998), 'Political Reform in Japan: Is It Becoming More Democratic?' (Cardiff, CA: JPRI Working Paper, No. 42, February).

Broadbent, Jeffrey (1998), Environmental Politics in Japan: Networks of Power and Protest (Cambridge: Cambridge University Press).

Calder, Kent (1988), Crisis and Compensation: Public Policy and Political Stability in Japan, 1949-1986 (Princeton, NJ: Princeton University Press).

Cossa, Ralph (1996), 'Okinawa Bases Referendum: What Will It Prove?', PacNet Newsletter 36, 6 September, http://www.csis.org/pacfor/pac36.html.

Defense Agency (1997), Defense of Japan, 1997 (Tokyo: The Japan Times).

Defense Agency (1998), Defense of Japan, 1998 (Tokyo: The Japan Times). 
Eldridge, Robert (1997), 'The 1996 Okinawa Referendum on U.S. Base Reductions: One Question, Several Answers', Asian Survey XXXVII, 10: 879 904.

George Mulgan, Aurelia (1999), 'Strategic Update-Japan' (Canberra: paper presented to the Australian Defence Studies Centre 'Strategic Update '99' Conference, Parliament House, 28 September).

Giarra, Paul S. (1999), 'U.S. Bases in Japan: Historical Background and Innovative Approaches', in Michael J. Green and Patrick M. Cronin, eds, The U.S.-Japan Alliance: Past, Present, and Future (New York: Council on Foreign Relations Press).

Hirose Michisada (1981), Hojokin to Seikento [Subsidies and the ruling party] (Tokyo: Asahi Shinbunsha).

Jameson, Sam (1998), 'One-Nation Pacifism: Japan's Security Problems and Challenges to the US-Japan Alliance', Asia-Pacific Review 5, 3: 65-86.

Johnson, Chalmers (1996), 'American Military Bases in San Diego and Okinawa', JPRI Critique III, 6.

Johnson, Chalmers (1998), 'The U.S. General Accounting Office's Report on the Proposed Marine Corps Floating Heliport Off Okinawa' (Cardiff, CA: JPRI Occasional Paper No. 14, June).

JPRI Staff (1996), 'Japan Policy Research Institute Special Report: Okinawa Update', JPRI Critique III, 7.

JPRI Staff (1997), 'Governor Ota at the Supreme Court of Japan', JPRI Critique IV, 2.

JPRI Staff (1998), 'The LDP Takes Over in Okinawa', JPRI Critique V, 11.

Lesbirel, Hayden (1998), NIMBY Politics in Japan: Energy Siting and The Management of Environmental Conflict (Ithaca, NY: Cornell University Press).

Maki, John M. (1964), Court and Constitution in Japan: Selected Supreme Court Decisions, 1948-60 (Seattle, WA: University of Washington Press) quoted in Stockwin (1982: 207).

McCormack, Gavan (1998), 'Okinawan Dilemmas: Coral Islands or Concrete Islands?' (Cardiff, CA: JPRI Working Paper No. 45, April).

McCormack, Gavan and Yoshio Sugimoto (1986), 'Introduction: Democracy and Japan', in Gavan McCormack and Yoshio Sugimoto, eds, Democracy in Contemporary Japan (New York/London: M.E. Sharpe).

McKean, Margaret A. (1981), Environmental Protest and Citizen Politics in Japan (Berkeley, CA: University of California Press). 
McKean, Margaret (1993), 'State Strength and Public Interest', in Gary D. Allinson and Yasunori Sone, eds, Political Dynamics in Contemporary Japan Ithaca, NY and London: Cornell University Press).

Millard, Mike (1998), 'Okinawa, Then and Now' (Cardiff, CA: JPRI Occasional Paper, No. 11, February).

Miyagi Yasuhiro (1998), 'Nago Citizens Act Against the Nago Heliport: A Brief Chronology', JPRI Critique V, 3.

Nomura Jiro (1987), Saiko Saibansho [The Supreme Court] (Tokyo: Kodansha).

Patterson, Torkel (1996), 'Commentary: Okinawa Situation is Improved, But American Forces Face a Transition Over the Long Haul', PacNet Newsletter 40, 4 October, www.csis.org/pacfor/pac40.html.

Ramseyer, J. Mark and Frances McCall Rosenbluth (1993), Japan's Political Marketplace (Cambridge/London: Harvard University Press).

Sakurada, Daizo (1998), 'Why We Need the US-Japan Security Treaty', AsiaPacific Review 5, 1: 13-38.

Smith, Beverly (1986), 'Democracy Derailed: Citizens' Movements in Historical Perspective', in Gavan McCormack and Yoshio Sugimoto, eds, Democracy in Contemporary Japan (New York/London: M.E. Sharpe).

Smith, Patrick (1998), 'Masahide Ota and the End of an Ideal', JPRI Critique V, 11.

Smith, Patrick (1999), 'Japan: The Enigma of American Power', Washington Quarterly 22, 2: 195-212.

Stockwin, Arthur (1982), Divided Politics in a Growth Economy, 2nd edn (London: Weidenfeld and Nicolson).

Stockwin, J.A.A. (1999), Governing Japan (London/Oxford: Blackwell).

Taira, Koji (1997), 'The United States, Japan and Okinawa: Conflict and Compromise, 1995-96' (Cardiff, CA: JPRI Working Paper, No. 28, January).

Takazao Suzuyo (1998), 'Human Rights Violations and Environmental Destruction Caused by Stationing U.S. Troops in Okinawa', JPRI Critique V, 3.

van Wolferen, Karel (1989), The Enigma of Japanese Power: People and Politics in a Stateless Nation (London: Macmillan).

Zaisei Chosakai, ed. (1998), Heisei 10-Nendo Hojokin Soran [A compendium of subsidies for 1998] (Tokyo: Nihon Densan Kikaku Kabushiki Kaisha).

Zaisei Kinyu Tokei Geppo [Ministry of Finance Statistics Monthly] (various issues), Okurasho, Zaisei Kinyu Kenkyujo, ed. (Tokyo: Okurasho Insatsu Kyoku). 


\title{
Department of International Relations
}

\section{PUBLICATIONS}

\author{
Working PAPERs:

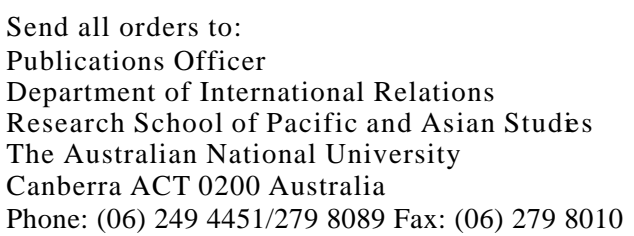

as at 1 January 2000
WP1989/1 The Changing Central Balance and Australian Policy, by Coral Bell WP1989/2 Agricultural Trade and Australian Foreign Policy in the 1990s, by Stuart Harris
WP1989/3 The Politics of Reassurance: Egypt and the Arab World, 1977-1987, by Ralph King
WP1989/4 Analysing the Impact of International Sanctions on China, by Peter Van Ness WP1989/5 Economic Change in the International System Implications for Australia's Prospects, by Stuart Harris
WP1990/1 Middle Power Leadership and Coalition Building: The Cairns Croup and the Uruguay Round, by Andrew Fenton Cooper and Richard A. Higgott
WP1990/2 The Soviet Far East, by Geoff Jukes
WP1990/3 The Environmental Challenge: The New International Agenda, by Stuart Harris
WP1990/4 India in Southwest Asia, by Amin Saikal
WP1990/5 Is Unilateral Trade Liberalisation the Answer? by Trevor Matthews and John Ravenhill
WP1990/6 The Politics of Baltic Nationalisms, by William Maley
WP1990/7 Peacekeeping in the South Pacific: Some Questions for Prior Consideration, by Greg Fry
WP1990/8 Informal Theories of Rationality, by James L. Richardson
WP1990/9 The Limits to Liberalisation in Industrialising Asia: Three Views of the State, by James Cotton
WP1990/10 The Influence of the United Nations on the Antarctic System: a Source of Erosion or Cohesion? by Stuart Harris
WP1991/1 International Trade, Ecologically Sustainable Development and the GATT, by Stuart Harris
WP1991/2 Middle Powers and International Sanctions: Generic Theory Reconsidered, by Kim Richard Nossal
WP1991/3 Continuity and Change in Cooperative International Regimes: The Politics of the Recent Environment Debate in Antarctica, by Lorraine M. Elliott
WP1991/4 Foreign Policy Analysis, International Relations Theory, and Social Theory: Critique and Reconstruction, by Ian Bell
WP1991/5 China as a Third World State: Foreign Policy and Official National Identity, by Peter Van Ness
WP1991/6 The Drawbacks of the Detached View: Russia, the USSR and the Pacific, by Artem Rudnitskiy



Change? by James Cotton

WP1991/8 Australia and the South Pacific: From 'Strategic Denial' to 'Constructive Commitment', by Greg Fry

WP1991/9 Implementing Foreign Policy: The Environmental Challenge, by Stuart Harris

After the Cold War and the Gulf War: Prospects for Security in the Asia-Pacific, by Andrew Mack

WP1992/2 Questions About a Post-Cold War International Order, by J.L. Richardson New Hierarchies in East Asia: The Post-Plaza Division of Labour, by Mitchell Bernard and John Ravenhill

WP1992/4

WP1992/5

WP1992/6

WP1992/7

WP1992/8

Federalism and Australian Foreign Policy, by Stuart Harris

Moving Target-Korea's Nuclear Proliferation Potential by Peter Hayes

The Economic Aspects of Pacific Security, by Stuart Harris

The Gulf War and Australian Political Culture, by James L. Richardson

The Case For a Nuclear Weapon-Free Zone in Northeast Asia

by Andrew Mack

WP1992/9

Nuclear Dilemmas: Korean Security in the 1990s, by Andrew Mack

WP1992/10

Arms Proliferation in the Asia-Pacific: Causes and Prospects for Control

by Andrew Mack

WP1993/1 The Practice of Common Security: China's Borders with Russia and India, by Gary Klintworth

WP1993/2 Strategic Trade Policy: The East Asian Experience, by Trevor Matthews and John Ravenhill

WP1993/3 Environmental Regulation, Economic Growth and International Competitiveness, by Stuart Harris

WP1993/4 The Environment and Sustainable Development: An Australian Social Science Perspective, by Stuart Harris

WP1993/5 Gaddis' Lacuna: Foreign Policy Analysis and the End of the Cold War, byValerie Hudson

WP1993/6

WP1993/7

WP1993/8

The Return of Practical Reason, by Hayward R. Alker, Jr.

An American New World Order?, by James L. Richardson

Concepts of Security in the Post-Cold War, by Andrew Mack

WP1993/9

Australian Security in the 1990s, by Andrew Mack

WP1993/10 Nuclear-Free Zones in the 1990s, by Andrew Mack

WP1994/1 Inter-Civilisation Conflict: A Critique of the Huntington Thesis,

by Jacinta O'Hagan

WP1994/2 The Future of Asia-Pacific Security Studies in Australia, by Pauline Kerr and Andrew Mack

WP1994/3

WP1994/4

Australia's Regional Security Environment, by Stuart Harris

Policy Networks and Economic Cooperation: Policy Coordination in the AsiaPacific Region, by Stuart Harris

WP1994/5

North Korea's Nuclear Program: the Options are Shrinking, by Andrew Mack

WP1994/6

The Asia-Pacific: Geopolitical Cauldron or Regional Community?

by James L. Richardson

WP1994/7 'Climbing Back onto the Map?': The South Pacific Forum and the New Development Orthodoxy, by Greg Fry

WP1994/8 Human Rights and Cultural Specificity: The Case of Papua New Guinea, by Michael Jacobsen 


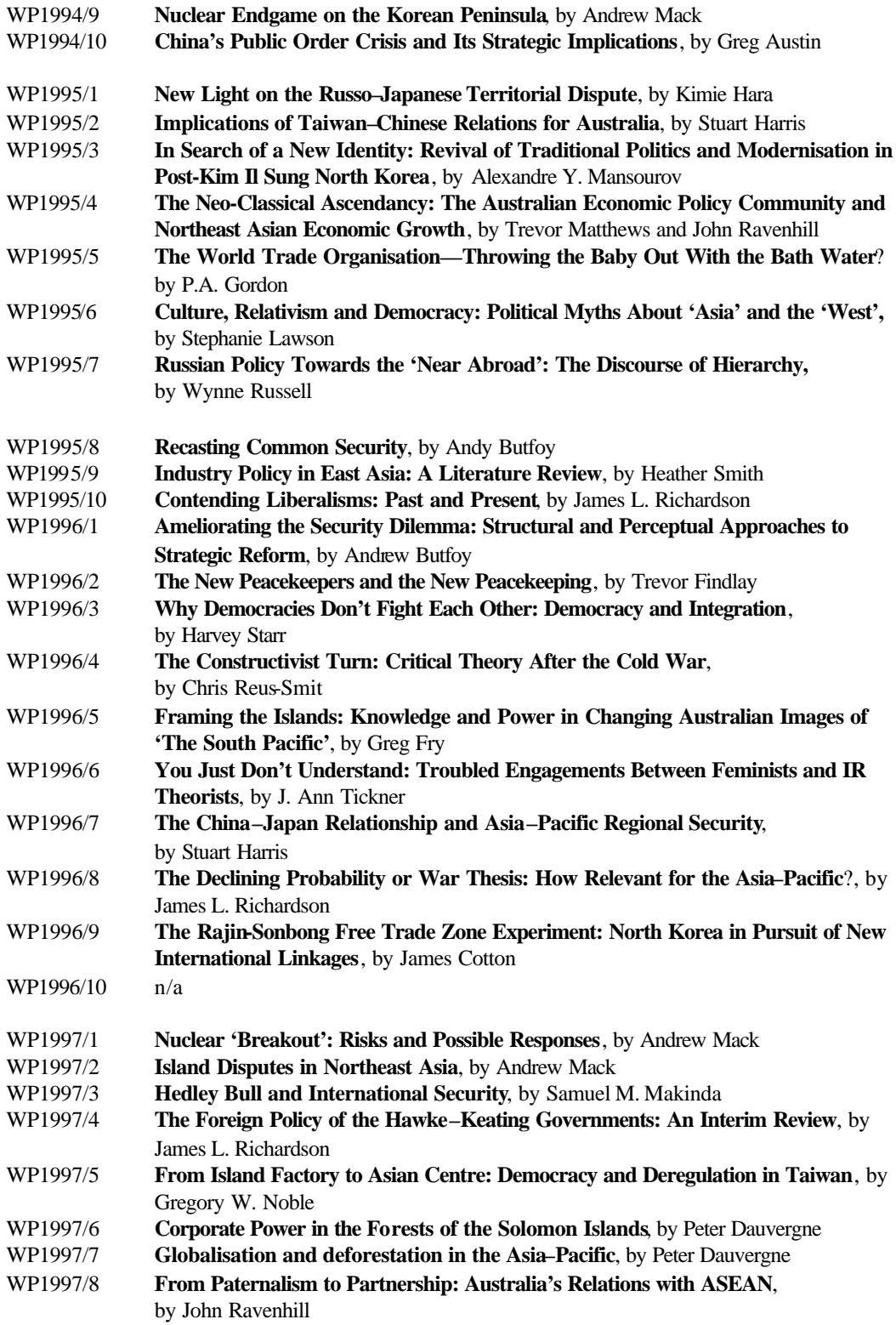

Nuclear 'Breakout': Risks and Possible Responses, by Andrew Mack

Island Disputes in Northeast Asia, by Andrew Mack

Hedley Bull and International Security, by Samuel M. Makinda

The Foreign Policy of the Hawke-Keating Governments: An Interim Review, by James L. Richardson

From Island Factory to Asian Centre: Democracy and Deregulation in Taiwan, by Gregory W. Noble

Corporate Power in the Forests of the Solomon Islands, by Peter Dauvergne Globalisation and deforestation in the Asia-Pacific, by Peter Dauvergne From Paternalism to Partnership: Australia's Relations with ASEAN, by John Ravenhill 


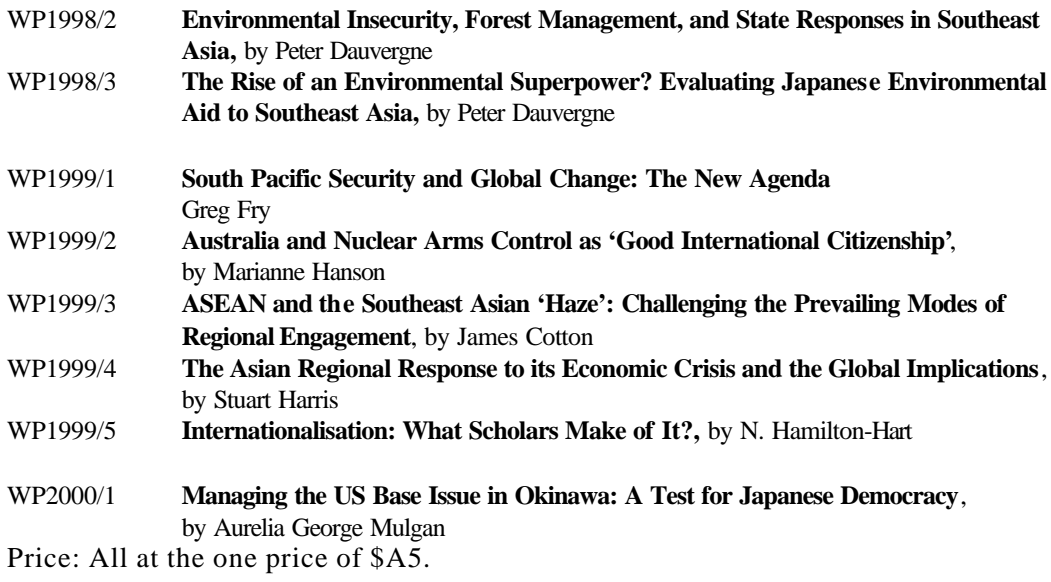

\section{Canberra S TUdies in W ORLdAfFairs:}

Send all orders to:

Reply paid 440, Bibliotech

ANUTECH

Canberra ACT 0200 Australia

Telephone: (616/06) $2493811 / 5662$

Fax Order: IDD (616) STD (06) 2571433

CS21 Politics, Diplomacy and Islam: Four Case Studies, edited by Coral Bell $\$ \$ 10.00$

CS22 The Changing Pacific: Four Case Studies, edited by Coral Bell \$10.00

CS23 New Directions in International Relations? Australian Perspectives, edited by Richard Higgott

CS24 Australia and the Multinationals: A Study of Power and Bargaining in the 1980s, by Neil Renwick

CS27 Northeast Asian Challenge: Debating the Garnaut Report, edited by J.L. Richardson

CS28 The ANZUS Documents, edited by Alan Burnett with Thomas-Durell Young and Christine Wilson

CS29 Human Rights in the Asia-Pacific Region, edited by John Girling \$15.00

CS30 International Relations: Global and Australian Perspectives on an 


\section{STUDIES In W ORLDAFFAIRS:}

Send all orders to:

Allen \& Unwin Pty Ltd

9 Atchison Street

St Leonards NSW 2605 Australia

Ph: (02) 901 4088, Fax: (02) 9062218

Ethics and Foreign Policy, edited by Paul Keal

Korea Under Roh Tae-woo: Democratisation, Northern Policy, and

Inter-Korean Relations, edited by James Cotton

Asian-Pacific Security After the Cold War, edited by T.B. Millar and James Walter

The Post-Cold War Order: Diagnoses and Prognoses, edited by Richard Leaver and James L. Richardson

Dependent Ally: A Study in Australian Foreign Policy, 3rd ed., by Coral Bell

A Peaceful Ocean? Maritime Security in the Pacific in the Post-Cold War Era, edited by Andrew Mack

Asian Flashpoint: Security and the Korean Peninsula edited by Andrew Mack

Taiwan in the Asia-Pacific in the 1990s, edited by Gary Klintworth

Pacific Cooperation: Building Economic and Security Regimes in the Asia-Pacific,

edited by Andrew Mack and John Ravenhill

The Gulf War: Critical Perspectives, edited by Michael McKinley

$\$ 24.95$

Search for Security: The Political Economy of Australia's Postwar Foreign and

Defence Policy, by David Lee

The New Agenda for Global Security, Cooperating for Peace and Beyond,

edited by Stephanie Lawson

Presumptive Engagement: Australia's Asia-Pacific Security Policy in the 1990s, by Desmond Ball and Pauline Kerr

Discourses of Danger and Dread Frontiers: Australian Defence and Security

Thinking After the Cold War, edited by Graeme Cheeseman and Robert Bruce

Pacific Rim Development: Integration and Globalisation in the Asia-Pacific

Economy, edited by Peter J. Rimmer

Evatt to Evans: The Labor Tradition in Australian Foreign Policy,

edited by David Lee and Christopher Waters

Cambodia—From Red to Blue: Australia's Initiative for Peace, by Ken Berry

Asia-Pacific Security: The Economics-Politics Nexus, edited by Stuart Harris

and Andrew Mack

China's Ocean Frontier: International Law, Military Force and National

Development by Greg Austin

Weak and Strong States in Asia-Pacific Societies, edited by Peter Dauvergne

Australian Outlook: a History of the Australian Institute of International Affairs by J.D. Legge

Transforming Asian Socialism: China and Vietnam Compared, by Anita Chan, 


\section{Australian Foreign Policy Papers}

Australian Foreign Policy Papers are published by the Australian Foreign Policy Publications Programme in the Department of International Relations:

Send all orders to:

Reply paid 440, Bibliotech

ANUTECH

Canberra ACT 0200 Australia

Telephone: (616/06) 249 3811/5662

Fax Order: IDD (616) STD (06) 2571433

Australia's Alliance Options: Prospect and Retrospect in a World of Change,

by Coral Bell

Coping With Washington: Players, Conventions and Strategies, by Davis Bobrow

The European Community in Context by John Groom

Australia's Human Rights Diplomacy, by Ian Russell, Peter Van Ness and

Beng-Huat Chua

Selling Mirages: The Politics of Arms Trading by Graeme Cheeseman

The Search for Substance: Australia-India Relations into the Nineties and Beyond,

by Sandy Gordon

Protecting the Antarctic Environment: Australia and the Minerals Convention,

by Lorraine Elliott

$\$ 15.00$

$\$ 15.00$

Australia's Taiwan Policy 1942-1992, by Gary Klintworth

$\$ 15.00$

$\$ 20.00$

Australia and the New World Order: Evatt in San Francisco, 1945, by W.J. Hudson

$\$ 20.00$

The Beijing Massacre: Australian Responses, by Kim Richard Nossa

$\$ 15.00$

The Pacific Patrol Boat Project: A Case Study of Australian Defence Cooperation

by Anthony Bergin

A Select Bibliography of Australia's Foreign Relations, 1975-1992, compiled by

Pauline Kerr, David Sullivan and Robin Ward

$\$ 10.00$

Australia's Evolving American Relationship: Interests, Processes and Prospects

* Plus $\$ 3.00$ postage and packaging per copy ordered. 
DEPARTMENT OF INTERNATIONAL RELATIONS

Publications Order Form

WORKING PAPERS ONLY

Please Supply

Copies of IR Working Paper No..................... Copies of IR Working Paper No..

Copies of IR Working Paper No........................ Copies of IR Working Paper No..

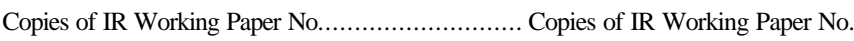

Copies of IR Working Paper No...................... Copies of IR Working Paper No.....

Copies of IR Working Paper No...................... Copies of IR Working Paper No

* All Working Papers are \$A5.

Method of Payment (please tick)

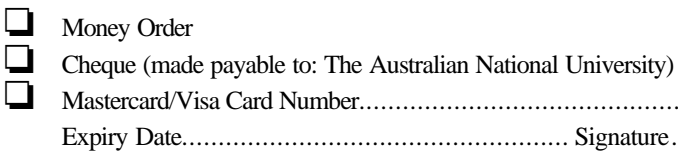

For Overseas Orders: Payment by Mastercard/Visa or by Bank Draft in Australian Dollars only, payable to Australian National University.

Name/Organisation:

Postal Address:

Suburb: .................................. State: ......................... Postcode:

Signature: ...................................................... Date:

Please forward completed form and payment to:

Publications Officer

Department of International Relations

Research School of Pacific and Asian Studies

Australian National University

CANBERRA ACT 0200 AUSTRALIA

Phone: (06) 249 4451/279 8089, Fax: (06) 2798010

Email: robin.ward@coombs.anu.edu.au 
